\section{Драгана Грујић}

dragana.grujic@fil.bg.ac.rs

Гордана Ђоковић

gordana.djokovic@fil.bg.ac.rs

Универзитет у Београду

Филолошки факултет https://doi.org/10.18485/knjiz.2021.11.11.11

УДК: 016:64ЖЕНСКИ СВЕТ(497.113)"1904/1907"

014.3ЖЕНСКИ СВЕТ(497.113)"1904/1907"

Стручни рад

\title{
Библиографија часописа Женски свет: лист добротворних задруга Српкиња: V део (1904-1907) ${ }^{1}$
}

\begin{abstract}
Библиографија представља пети наставак библиографије часописа Женски свет: лист добротворних задруга Српкиња. Обухвата четири године излажења часописа, од 1904. до 1907. године, и садржи 918 библиографских јединица, описаних de visu језиком и писмом публикације. Библиографија је подељена на четири целине хронолошки, према години излажења, док су бројеви библиографских јединица дати у континуитету. У оквиру сваке целине, јединице су азбучно распоређене према презимену аутора, односно наслову чланка - када је реч о текстовима који нису потписани или су потписани иницијалима. Уз библиографски опис дате су кратке анотације које ближе осликавају садржину. У складу са информативним захтевима заступљени су обједињени регистри који из библиографског описа издвајају наслов и предмет.
\end{abstract}

Кључне речи: библиографија, часопис Женски свет (1904-1907)

\section{4.}

1.

АНЕГДОТЕ из живота / [превела] Љубица Вучетићева // Год. 19, бр. 1 (1904), стр. 810.

- Књижевност

2.

АНЕГДОТЕ из живота / с француског превела Violette // Год. 19, бр. 2 (1904), стр. 34-36.

- Књижевност

3.

АНЕГДОТЕ из живота / с француског превела Violette // Год. 19, бр. 3 (1904), стр. 53-54.

- Књижевност

4.

БАЈИЋ, Исидор 
Српкиња / компоновао Исидор Бајић ; речи од Јована Живојновића // Год. 19, бр. 12 (1904), стр. 274-275.

- Музика / Ноте

5.

БАНДИЋ, Даница

Ева! : (дијалог) / Даница Бандић // Год. 19, бр. 4 (1904), стр. 84-85.

- Књижевност

6.

БЕЛОВИЋ, Јелица

Драгоценост наших народних везова / пише Јелица Беловићева // Год. 19, бр. 4 (1904), стр. 75-76.

- Књижевност

7.

БЕЛОВИЋ, Јелица

Историја наше лијепе чеврме / пише Јелица Беловићева // Год. 19, бр. 6 (1904), стр. 131-132.

- Женско питање / Ручни рад

8.

БЕРЗЕЦИЈА, Виктор

Узвишена племенитост / од Виктор Берзеција ; [превео] с италијанског Јеша // Год. 19, бр. 4 (1904), стр. 88-90.

- Књижевност

9.

БОЦАРИЋ, Ана

Почетница - глумица : монолог / написала Ана Боцарић // Год. 19, бр. 12 (1904), стр. 275-276.

- Књижевност

10.

БРАНКОВИЋ, Милка М.

Последњи састанак / Милка М. Бркановићева // Год. 19, бр. 5 (1904), стр. 111-112.

- Књижевност

11.

ВАСПИТАЛИШТА и „клостери“ / С. Вера М. К. // Год. 19, бр. 9 (1904), стр. 192-196.

- Женско питање / Васпитање

12.

ВИЛКОКС, Ела Вилер

Жена / пише Ella Wheeler Wilcox // Год. 19, бр. 7 (1904), стр. 152.

- Женско питање 
13.

ВРТАРСКА школа за женске / прев. Савка // Год. 19, бр. 1 (1904), стр. 6-7.

- Женско питање / Образовање

14.

ГАВРИЛОВИЋ, Миливоје М.

Слава ти Боже! / Миливоје М. Гавриловић // Год. 19, бр. 1 (1904), стр. 6.

- Књижевност

15.

ГАЈИЋ, Жарко

Моћ љубави / Жарко Гајић // Год. 19, бр. 1 (1904), стр. 10.

- Књижевност

16.

ГАЈИЋ, Жарко

Моја вича / Жарко Гајић // Год. 19, бр. 3 (1904), стр. 50.

- Књижевност

17.

ГАЈИЋ, Жарко

Монах / Жарко Гајић // Год. 19, бр. 3 (1904), стр. 66.

- Књижевност

18.

ГЛАСНИК // Год. 19, бр. 1 (1904), стр. 21-22

- Вести

19.

ГЛАСНИК // Год. 19, бр. 2 (1904), стр. 46-47.

- Вести

20.

ГЛАСНИК // Год. 19, бр. 3 (1904), стр. 67-69.

- Вести

21.

ГЛАСНИК // Год. 19, бр. 4 (1904), стр. 91-94.

- Вести

22.

ГЛАСНИК // Год. 19, бр. 5 (1904), стр. 115-117.

- Вести

23. 
- Вести

ГЛАСНИК // Год. 19, бр. 6 (1904), стр. 140-141.

24.

ГЛАСНИК // Год. 19, бр. 7 (1904), стр. 162.

- Вести

25.

ГЛАСНИК // Год. 19, бр. 8 (1904), стр. 187-189.

- Вести

26.

ГЛАСНИК // Год. 19, бр. 9 (1904), стр. 209-211.

- Вести

27.

ГЛАСНИК // Год. 19, бр. 10 (1904), стр. 235-237.

- Вести

28.

ГЛАСНИК // Год. 19, бр. 11 (1904), стр. 259-260.

- Вести

29.

ГЛАСНИК // Год. 19, бр. 12 (1904), стр. 277-279.

- Вести

30.

ГОНЗАЛЕС , Луис 87.

Коза / Luis Gonzales Gil ; превео Милан Л. Поповић // Год. 19, бр. 4 (1904), стр. 86-

- Књижевност

31.

ГОСПОЂИ Тинки Лукићки, врсној чланици српске народне позоришне дружине / J. Р-к. // Год. 19, бр. 12 (1904), стр. 268.

- Књижевност

32.

ГОСПОЪИЦИ Н...: (из збирке „Ожучено срце“) / Александар // Год. 19, бр. 4 (1904), стр. 95.

- Књижевност

33.

ГРГУРОВА, Милка 

41-45.

Породица Смиљићева [Део I] / написала Милка Гргурова // Год. 19, бр. 2 (1904), стр.

- Књижевност

34.

ГРГУРОВА, Милка

Породица Смиљићева [Део II] / написала Милка Гргурова // Год. 19, бр. 3 (1904), стр. 62-66.

- Књижевност

35.

ДАЛ’ је / Томир // Год. 19, бр. 7 (1904), стр. 149.

- Књижевност

36.

ДА л’те љубим? / Рајко // Год. 19, бр. 4 (1904), стр. 86.

- Књижевност

37.

ДАСКАЛОВИЋ, Владимир Г.

Срце моје / Владимир Г. Даскаловић // Год. 19, бр. 5 (1904), стр. 115.

- Књижевност

38.

ДВЕ сестрице...две љубице / В. К. Љубисав // Год. 19, бр. 4 (1904), стр. 76.

- Књижевност

39.

ДЕВОЈАЧКА друштва и наше добротворне задруге Српкиња // Год. 19, бр. 12 (1904), стр. 265-266.

- Женско питање / Женски покрети

40.

ДЕТИњ бол / с немачког К. Х. // Год. 19, бр. 11 (1904), стр. 253-258.

- Књижевност

41.

ДИМА, Душан J.

Богиња поезије и Српкиња / Душан Ј. Дима // Год. 19, бр. 5 (1904), стр. 99-100.

- Књижевност

42.

ДОПИС // Год. 19, бр. 1 (1904), стр. 10-11.

- Вести

43. 
- Вести

ДОПИСИ / Вједи // Год. 19, бр. 2 (1904), стр. 37-38.

44.

ДОПИСИ // Год. 19, бр. 3(1904), стр. 55-57.

- Вести

45.

ДОПИСИ // Год. 19, бр. 12 (1904), стр. 272-273.

- Женско питање / Женски покрети

46.

ДР. Илија Вучетић // Год. 19, бр. 8 (1904), стр. 169.

- Некролог

47.

ДР. Јован Јовановић-Змај // Год. 19, бр. 7 (1904), стр. 145.

- Биографије / Некролог

48.

ЂУЛИНАЦ, В.

О женама / В. Ђулинац // Год. 19, бр. 11 (1904), стр. 241-245.

- Женско питање

49.

ЕМИЛИЈА Мунчићка рођ. Векецки : народна добротворка // Год. 19, бр. 6 (1904), стр. 121-124.

- Биографије / Некролог

50.

ЖИВОЈИНОВИЋ, Јован

Српски походи : говорила госпођица Бојана Дракулићева, други дан Божића 1903. год. на забави срп. певачког друштва „Невен“-а у Новом Саду / Ј. [Јован] Живојиновић // Год. 19, бр. 2 (1904), стр. 26-28.

- Књижевност

51.

ЖИВОЈНОВИЋ, Јован

Звони на јутрење / донекле по туђој замисли саставио Јован Живојновић // Год. 19, бр. 6 (1904), стр. 124-126.

- Књижевност

52.

ЖИВОЈНОВИЋ, Јован 
Од Косова до црнога Ђорђа / Ј. Ж. [Јован Живојновић] // Год. 19, бр. 7 (1904), стр. 151.

- Књижевност

53.

ЖИВОЈНОВИЋ, Јован

Сретан пастир : мелодрама / Јова Живојновић // Год. 19, бр. 8 (1904), стр. 171-175.

- Књижевност

54.

ЖИВОЈНОВИЋ, Јован

Југ-Богданов дом : мелодрама из јуначке српске старине / [Јован Живојновић] // Год. 19, бр. 9 (1904), стр. 196-200.

- Књижевност

55.

ЖИВОЈНОВИЋ, Јован

Југ-Богданов дом : мелодрама из јуначке српске старине : (свршетак) / Јован Живојновић // Год. 19, бр. 10 (1904), стр. 221-226.

- Књижевност

56.

ЖИВОЈИНОВИЋ, Јован

Шта је највећа сила : говориће гђица Бојана Дракулићева на интернационалној забави у Н. Саду, о ускрсу 1904. у корист сироте деце / Јован Живојиновић // Год. 19, бр. 4 (1904), стр. 75.

- Књижевност

57.

ЗА домаћице // Год. 19, бр. 1 (1904), стр. 20.

- Женско питање / Савети

58.

ЗА домаћице // Год. 19, бр. 3 (1904), стр. 70.

- Женско питање / Савети

59.

ЗА домаћице // Год. 19, бр. 4 (1904), стр. 95.

- Женско питање / Савети

60.

ЗА домаћице // Год. 19, бр. 5 (1904), стр. 118.

- Женско питање / Савети

61.

ЗА домаћице // Год. 19, бр. 6 (1904), стр. 142. 
- Женско питање / Савети

62.

ЗА домаћице // Год. 19, бр. 7 (1904), стр. 165-166.

- Женско питање / Савети

63.

ЗА домаћице // Год. 19, бр. 8 (1904), стр. 190-191.

- Женско питање / Савети

64.

ЗА домаћице // Год. 19, бр. 9 (1904), стр. 212.

- Женско питање / Савети

65.

ЗА домаћице // Год. 19, бр. 10 (1904), стр. 238-239.

- Женско питање / Савети

66.

ЗА домаћице // Год. 19, бр. 11 (1904), стр. 262.

- Женско питање / Савети

67.

ЗА домаћице // Год. 19, бр. 12 (1904), стр. 282.

- Женско питање / Савети

68.

ЗАШТО? / Каја // Год. 19, бр. 9 (1904), стр. 212.

- Књижевност

69.

ЗАШТО ми с нова? / А. // Год. 19, бр. 8 (1904), стр. 180.

- Књижевност

70.

ЗДРАВЉЕ // Год. 19, бр. 3 (1904), стр. 70.

- Здравље

71.

ЗМАЈ песнику / Др. В. М. // Год. 19, бр. 8 (1904), стр. 189-190.

- Књижевност

72.

ЗОРИЋ, Душан С.

Мешај се ... / Душан С. Зорић // Год. 19, бр. 10 (1904), стр. 235-237.

- Књижевност 
73.

ИСПИХ пехар / Томир // Год. 19, бр. 11 (1904), стр. 259.

- Књижевност

74.

ЈАВАН рачун // Год. 19, бр. 3 (1904), стр. 71-72.

- Вести

75.

ЈАВАН рачун // Год. 19, бр. 6 (1904), стр. 143.

- Женско питање / Женски покрети / Вести

76.

ЈАВНА захвала // Год. 19, бр. 2 (1904), стр. 48.

- Вести

77.

ЈАВНЕ захвале // Год. 19, бр. 1 (1904), стр. 23.

- Вести

78.

ЈАВНЕ захвале // Год. 19, бр. 5 (1904), стр. 120.

- Вести

79.

ЈЕДАН поглед на - Женско питање у нас Срба // Год. 19, бр. 3 (1904), стр. 49-50.

- Женско питање / Образовање

80.

ЈЕДНУ сузу твоју / Томир // Год. 19, бр. 9 (1904), стр. 209.

- Књижевност

81.

ЈЕЛИ Београд / Олга // Год. 19, бр. 1 (1904), стр. 14.

- Књижевност

82.

ЈОШ нешто о српском православном девојачком васпиталишту у Будимпешти // Год. 19, бр. 8 (1904), стр. 170.

- Женско питање / Васпитање

83.

КАД је женска лепа / Булован - Белегишанин // Год. 19, бр. 4 (1904), стр. 73-74.

- Женско питање 
84.

КАЛИЋ, Даринка

Циљ женског образовања / предавала на читаон. селу 13. (26.) децембра 1903.

Даринка Калићева // Год. 19, бр. 1 (1904), стр. 3-6.

- Женско питање / Образовање

85.

КАРАБЕГОВИЋ, Авдо С.

У споменицу / Авдо Карабеговић // Год. 19, бр. 7 (1904), стр. 155.

- Књижевност

86.

КАРАБЕГОВИЋ, Авдо С.

Старчева елегија / С. А. [Авдо] Карабеговић // Год. 19, бр. 7 (1904), стр. 161.

- Књижевност

87.

КЬИЖЕВНОСТ // Год. 19, бр. 1 (1904), стр. 20.

- Вести / Књижевност

88.

КЊИЖЕВНОСТ // Год. 19, бр. 3 (1904), стр. 70-71.

- Вести / Књижевност

89.

КЊИЖЕВНОСТ // Год. 19, бр. 4 (1904), стр. 95-96.

- Вести / Књижевност

90.

КњИЖЕВНОСТ // Год. 19, бр. 5 (1904), стр. 119.

- Вести / Књижевност

91.

КњИЖЕВНОСТ // Год. 19, бр. 6 (1904), стр. 142.

- Вести / Књижевност

92.

КЊИЖЕВНОСТ// Год. 19, бр. 7 (1904), стр. 166-167.

- Вести / Књижевност

93.

КЊИЖЕВНОСТ // Год. 19, бр. 8 (1904), стр. 191.

- Вести / Књижевност

94.

КЊИЖЕВНОСТ // Год. 19, бр. 9 (1904), стр. 212-213. 
- Вести / Књижевност

95.

КЊИЖЕВНОСТ // Год. 19, бр. 10 (1904), стр. 239.

- Вести / Књижевност

96.

КњИЖЕВНОСТ // Год. 19, бр. 11 (1904), стр. 263.

- Вести / Књижевност

97.

КЊИЖЕВНОСТ // Год. 19, бр. 12 (1904), стр. 282-283.

- Вести / Књижевност

98.

КРАГУЈЕВИЋ, Милош П.

Да л' ће икад ... / Милош П. Крагујевић // Год. 19, бр. 8 (1904), стр. 186.

- Књижевност

99.

КРСТИЋ, Олга 181.

Отворено писмо г-ђици Зори Вучетићевој / Олга Крстић // Год. 19, бр. 8 (1904), стр.

- Женско питање / Васпитање

100.

ЛОТИЋ, Љубомир

О Змају Јовану Јовановићу / од Љубомира Лотића // Год. 19, бр. 5 (1904), стр. 100105.

- Биографије

101.

ЛУњЕВИЦА Влада М.

Поточић / Влада М Луњевица // Год. 19, бр. 5 (1904), стр. 109.

- Књижевност

102.

ЛУњЕВИЦА Јела М.

Верење / Јела М. Луњевица // Год. 19, бр. 4 (1904), стр. 88.

- Књижевност

103.

ЛУњЕВИЦА, Јела М.

Моја прва дугачка хаљина : посвећено мојој пријатељици Олги Арсеновићевој Сомборкињи / Јела М. Луњевица // Год. 19, бр. 5 (1904), стр. 112-114.

- Књижевност 
104.

ЛУЊЕВИЦА, Јела М.

Уочи Иван-дана / Јела М. Луњевица // Год. 19, бр. 6 (1904), стр. 134.

- Књижевност

105.

ЉУБАВ : (Кнез Матерних) / В. К. - Љуб. // Год. 19, бр. 1 (1904), стр. 18.

- Књижевност

106.

ЉУБАВ / Хришћанка // Год. 19, бр. 1 (1904), стр. 1-2.

- Књижевност

107.

ЉУБАВ / Хришћанка // Год. 19, бр. 2 (1904), стр. 28.

- Књижевност

108.

МАЛОРУСКА песма / превео Бранко Малаћ // Год. 19, бр. 5 (1904), стр. 106.

- Књижевност

109.

МАТИЈАШЕВИЋ, Димитрије

БОСАНЧЕ / Димитрије Матиј... [Матијашевић] // Год. 19, бр. 11 (1904), стр. 281.

- Књижевност

110.

МИЛО ми је ... / Олга // Год. 19, бр. 7 (1904), стр. 156.

- Књижевност

111.

МИЛОВАНОВ, Љуба

Испрошена / Љуба Милованов // Год. 19, бр. 1 (1904), стр. 18-19.

- Књижевност

112.

МИТРОВИЋ, Исаије

Својој сеји Милки М. Бркановић / Исаије Митровић // Год. 19, бр. 1 (1904), стр. 19.

- Књижевност

113.

МИТРОВИЋ, Исаије

Хеј младости!... / Исаије Митровић // Год. 19, бр. 2 (1904), стр. 37.

- Књижевност 
114.

МИТРОВИЋ, Исаије

Природа снива... / Исаије Митровић // Год. 19, бр. 2 (1904), стр. 39.

- Књижевност

115.

МИТРОВИЋ, Исаије

О Боже! / Исаије Митровић // Год. 19, бр. 3 (1904), стр. 54.

- Књижевност

116.

МИТРОВИЋ, Исаије

Горо! / Исаије Митровић // Год. 19, бр. 9 (1904), стр. 204.

- Књижевност

117.

МНОГОЦЕЊЕНОЈ и уваженој госпођи Савки Ј. Суботић : (у знак дубока поштовања) / В. К. Љубисав // Год. 19, бр. 11 (1904), стр. 251.

- Књижевност

118.

МОЈА љубав : госпођици И. П. / Сл. // Год. 19, бр. 1 (1904), стр. 12.

- Књижевност

119.

МОЈА спасиља / Јова // Год. 19, бр. 12 (1904), стр. 273.

- Књижевност

120.

НА служби и за други пут / с руско Ј. Ћ. // Год. 19, бр. 7 (1904), стр. 153.

- Књижевност

121.

НАШИ дописи / Савка // Год. 19, бр. 6 (1904), стр. 132-133.

- Женско питање / Женски покрети / Вести

122.

НАШИ дописи // Год. 19, бр. 7 (1904), стр. 154.

- Женско питање / Женски покрети

123.

НЕОБИЧАН догађај једног ђака / с немачког Хр. Пурић // Год. 19, бр. 10 (1904), стр. 228-230.

- Књижевност

124. 
НЕРАНџИЋ-Брашован, Даринка

Боже! / Д. [Даринка] Неранџић-Брашованова // Год. 19, бр. 12 (1904), стр. 276.

- Књижевност

125.

НЕШТО о шећеру / А. М. М. // Год. 19, бр. 6 (1904), стр. 127-130.

- Образовање

126.

НИКОЛИЋ, Алекс М.

Цртице из живота Наполеона / Алекс М. Николић // Год. 19, бр. 4 (1904), стр. 77-78.

- Биографије

127.

НОВА народна тековина // Год. 19, бр. 5 (1904), стр. 97-99.

- Женско питање / Женски покрети

128.

НОВЕ музикалије // Год. 19, бр. 4 (1904), стр. 96.

- Вести

129.

НОВЕ музикалије // Год. 19, бр. 5 (1904), стр. 120.

- Вести

130.

НОВЕ музикалије // Год. 19, бр. 12 (1904), стр. 283.

- Вести / Музика

131.

НОВЕ слике // Год. 19, бр. 8 (1904), стр. 191.

- Вести / Уметност

132.

О јапанском женскињу / превео Мил. Л. Поповић // Год. 19, бр. 10 (1904), стр. 231232.

- Женско питање / Васпитање / Јапан

133.

О народној орнаментици // Год. 19, бр. 11 (1904), стр. 251.

- Уметност

134.

ОТКРИВАЊЕ Војислављевог споменика у Београду // Год. 19, бр. 5 (1904), стр. 106. - Вести 
135.

ПЕШИЋ, Лазар

Имао сам / Лазар Пешић Јованов // Год. 19, бр. 2 (1904), стр. 45.

- Књижевност

136.

ПЕШИЋ, Лазар

Пригодом смрти великана песника чика Јове Јовановића - Змаја / Лазар Пешић

Јованов // Год. 19, бр. 7 (1904), стр. 146.

- Књижевност

137.

ПЕШИЋ, Лазар

Фрушкогорска / Лазар Пешић Јованов // Год. 19, бр. 7 (1904), стр. 153.

- Књижевност

138.

ПИСМО уреднику „Женског света“ // Год. 19, бр. 9 (1904), стр. 200-202.

- Преписка

139.

ПИСМО уреднику „Женског света“ : (свршетак) / Михаила // Год. 19, бр. 10 (1904), стр. 226-227.

- Женско питање / Образовање

140.

ПОЗИВ на претплату / уредник // Год. 19, бр. 1 (1904), стр. 24.

- Вести

141.

ПОЛОЖАЈ васпитачица : по мађарском / М. М. Рођ. С. // Год. 19, бр. 2 (1904), стр. 29-32.

- Женско питање / Образовање

142.

ПОЛУДЕЛА / Јелисавета // Год. 19, бр. 1 (1904), стр. 8.

- Књижевност

143.

ПОПИЋ, Сергије

Синовици Смиљи / Сергије Попић // Год. 19, бр. 4 (1904), стр. 83.

- Књижевност

144.

ПОПОВИЋ, Јове Г.

Л’јеп је Стамбол / Јове Г. Поповић Босанац // Год. 19, бр. 12 (1904), стр. 266. 
- Књижевност

145.

ПОПОВИЋ, Милан Л.

Казао бих... / Милан Л. Поповић // Год. 19, бр. 3(1904), стр. 58.

- Књижевност

146.

ПОСЛЕДЊИ акорд / Томир // Год. 19, бр. 10 (1904), стр. 230.

- Књижевност

147.

ПРЕД буром / Дим. П. Стај. // Год. 19, бр. 7 (1904), стр. 164.

- Књижевност

148.

ПРОГРАМ српског православног васпиталишта у Будимпешти // Год. 19, бр. 7 (1904), стр. 148-149.

- Женско питање / Васпитање

149.

ПРОљЕТНИ звуци / Драгољуб // Год. 19, бр. 1 (1904), стр. 2-3.

- Књижевност

150.

ПРОљЕТНИ звуци / Драгољуб // Год. 19, бр. 2 (1904), стр. 32-33.

- Књижевност

151.

ПРОљЕТНИ звуци / Драгољуб // Год. 19, бр. 3 (1904), стр. 52.

- Књижевност

152.

ПРОљЕТНИ звуци / Драгољуб // Год. 19, бр. 4 (1904), стр. 78.

- Књижевност

153.

ПРОљЕТНИ звуци / Драгољуб // Год. 19, бр. 5 (1904), стр. 105.

- Књижевност

154.

ПРОљЕТНИ звуци / Драгољуб // Год. 19, бр. 6 (1904), стр. 130.

- Књижевност

155.

ПРОљЕТНИ звуци / Драгољуб // Год. 19, бр. 7 (1904), стр. 154. 
- Књижевност

156.

ПРОљЕТНИ звуци / Драгољуб // Год. 19, бр. 8 (1904), стр. 182.

- Књижевност

157.

ПРОљЕТНИ звуци / Драгољуб // Год. 19, бр. 9 (1904), стр. 202-203.

- Књижевност

158.

ПРОљЕТНИ звуци / Драгољуб // Год. 19, бр. 10 (1904), стр. 228.

- Књижевност

159.

ПРОљЕТНИ звуци / Драгољуб // Год. 19, бр. 11 (1904), стр. 245.

- Књижевност

160.

ПРОљЕТНИ звуци / Драгољуб // Год. 19, бр. 12 (1904), стр. 272.

- Књижевност

161.

ПРОСВЕТА // Год. 19, бр. 1 (1904), стр. 20.

- Образовање / Педагогија

162.

ПРОСВЕТА // Год. 19, бр. 3 (1904), стр. 70.

- Образовање / Педагогија

163.

ПРОСВЕТА // Год. 19, бр. 5 (1904), стр. 118.

- Образовање / Педагогија

164.

ПРОСВЕТА // Год. 19, бр. 6 (1904), стр. 142.

- Образовање / Педагогија

165.

ПРОСВЕТА // Год. 19, бр. 7 (1904), стр. 165.

- Образовање / Педагогија

166.

ПРОСВЕТА // Год. 19, бр. 8 (1904), стр. 190.

- Образовање / Педагогија 
167.

ПРОСВЕТА // Год. 19, бр. 10 (1904), стр. 238.

- Образовање / Педагогија

168.

ПРОСВЕТА // Год. 19, бр. 11 (1904), стр. 261-262.

- Образовање / Педагогија

169.

ПРОСЛАВА 70-годишњице гђе Савке Дра Јована Суботића // Год. 19, бр. 11 (1904), стр. 246-250.

- Вести / Биографије

170.

ПУРИЋ, Хрисанта

За утеху породици моје пријатељице J. Ђ. / Хрисанта Пурићка // Год. 19, бр. 11 (1904), стр. 261.

- Књижевност

171.

РАД добротворних задруга Српкиња // Год. 19, бр. 1 (1904), стр. 12-14.

- Женско питање / Женски покрети

172.

РАД добротворних задруга Српкиња // Год. 19, бр. 2 (1904), стр. 39-40.

- Женско питање / Женски покрети

173.

РАД добротворних задруга Српкиња // Год. 19, бр. 3 (1904), стр. 58-62.

- Женско питање / Женски покрети

174.

РАД добротворних задруга Српкиња // Год. 19, бр. 4 (1904), стр. 79-83.

- Женско питање / Женски покрети

175.

РАД добротворних задруга Српкиња // Год. 19, бр. 5 (1904), стр. 109-110.

- Женско питање / Женски покрети

176.

РАД добротворних задруга Српкиња // Год. 19, бр. 6 (1904), стр. 134-135.

- Женско питање / Женски покрети

177.

РАД добротворних задруга Српкиња // Год. 19, бр. 7 (1904), стр. 155.

- Женско питање / Женски покрети 
178.

РАД добротворних задруга Српкиња // Год. 19, бр. 9 (1904), стр. 203-204.

- Женско питање / Женски покрети

179.

РАД добротворних задруга Српкиња // Год. 19, бр. 10 (1904), стр. 230-231.

- Женско питање / Женски покрети

180.

РАД добротворних задруга Српкиња // Год. 19, бр. 11 (1904), стр. 252.

- Женско питање / Женски покрети

181.

РАДОСАВљЕВИЋ, Паја Р.

Психологија сполова / Паја Р. Радосављевић // Год. 19, бр. 8 (1904), стр. 175-180.

- Женско питање / Образовање

182.

РАЗНО / Јелица // Год. 19, бр. 4 (1904), стр. 95.

- Вести

183.

РАЗНО / Хришћанка // Год. 19, бр. 7 (1904), стр. 167.

- Вести

184.

РАЗНО // Год. 19, бр. 12 (1904), стр. 281-282.

- Вести

185.

САВКА Суботићка : (1834-1904) // Год. 19, бр. 10 (1904), стр. 217-221.

- Биографија / Некролог

186.

САДАШЊЕ Јапанкиње / с енглеског превела М. Г. // Год. 19, бр. 5 (1904), стр. 107109.

- Женско питање / Васпитање

187.

СЕБИЛЏИЈА : турска прича : [део I] / превод Раде Крајиновић // Год. 19, бр. 6 (1904), стр. 135-139.

- Књижевност

188. 
СЕБИЛџИЈА : турска прича : [део II] / превод Раде Крајиновић // Год. 19, бр. 7 (1904), стр. 156-161.

- Књижевност

189.

СЕБИЛЏИЈА : турска прича : [део III] / превод Раде Крајиновић // Год. 19, бр. 8 (1904), стр. 182-186.

- Књижевност

190.

СЕБИЛЏИЈА : турска прича : (свршетак) / превод Раде Крајиновић // Год. 19, бр. 9 (1904), стр. 204-208.

- Књижевност

191.

СРПКИЊАМА из уже Угарске // Год. 19, бр. 12 (1904), стр. 267.

- Женско питање

192.

СРПСКО православно девојачко 148.

Срп. прав. девојачко васпиталиште у Будимпешти // Год. 19, бр. 7 (1904), стр. 146-

- Женско питање / Васпитање

193.

СРПСКЕ забаве // Год. 19, бр. 9 (1904), стр. 214-216.

- Вести / Забава

194.

СРЦЕ моје / Зорка // Год. 19, бр. 2 (1904), стр. 40.

- Књижевност

195.

СТОГОДИШњА прослава у Србији // Год. 19, бр. 2 (1904), стр. 25-26.

- Образовање

196.

ТЕЛЕПАТИЈА : из доживљаја Ј....нин // Год. 19, бр. 7 (1904), стр. 150-151.

- Женско питање / Здравље

197.

УБИТАЧНОСТ моде / превео А. М. // Год. 19, бр. 12 (1904), стр. 268-271.

- Женско питање

198.

У слози је спас! / М. // Год. 19, бр. 3 (1904), стр. 51. 
- Женско питање / Женски покрети

199.

ЦАР моде / превела с италијанског О. С. // Год. 19, бр. 10 (1904), стр. 233-234.

- Женско питање

200.

ЦРНА кула / Драгољуб // Год. 19, бр. 4 (1904), стр. 90-91.

- Књижевност

201.

ЧЕЖЊА / Аниворис // Год. 19, бр. 11 (1904), стр. 251.

- Књижевност

202.

ЧИТУЉА // Год. 19, бр. 1 (1904), стр. 22.

- Вести / Некролог

203.

ЧИТУЉА // Год. 19, бр. 2 (1904), стр. 48.

- Вести / Некролог

204.

ЧИТУљА // Год. 19, бр. 3 (1904), стр. 69.

- Вести / Некролог

205.

ЧИТУљА // Год. 19, бр. 4 (1904), стр. 94.

- Вести / Некролог

206.

ЧИТУљА // Год. 19, бр. 5 (1904), стр. 117.

- Вести / Некролог

207.

ЧИТУљА // Год. 19, бр. 6 (1904), стр. 141.

- Вести / Некролог

208.

ЧИТУљА // Год. 19, бр. 7 (1904), стр. 164.

- Вести / Некролог

209.

ЧИТУљА // Год. 19, бр. 8 (1904), стр. 189-190.

- Вести / Некролог 
210.

ЧИТУљА // Год. 19, бр. 9 (1904), стр. 211.

- Вести / Некролог

211.

ЧИТУљА // Год. 19, бр. 10 (1904), стр. 237.

- Вести / Некролог

212.

ЧИТУЉА // Год. 19, бр. 11 (1904), стр. 260.

- Вести / Некролог

213.

ЧИТУљА // Год. 19, бр. 11 (1904), стр. 279-280.

- Вести / Некролог

214.

ЧУДОМИРОВИЋ, Миливоје

Радост за радост / Божићна приповетка Миливоја Чудомировића // Год. 19, бр. 1 (1904), стр. 14-18.

- Књижевност 


\section{5.}

215.

АНЕГДОТЕ из живота / с немачког преводи Violetta // Год. 20, бр. 3 (1905), стр. 5354.

- Књижевност

216.

АНЕГДОТЕ из живота / с немачког преводи Violetta // Год. 20, бр. 4 (1905), стр. 8182.

- Књижевност

217.

АНЕГДОТЕ из живота / с француског преводи Violetta // Год. 20, бр. 7/8 (1905), стр. 157-159.

- Књижевност

218.

БЕЛОВИЋ, Јелица

Наша народна умјетност / Јелица Беловић // Год. 20, бр. 4 (1905), стр. 73-75.

- Женско питање / Ручни рад

219.

БЕЛОВИЋ, Јелица

Наша народна умјетност / Јелица Беловић // Год. 20, бр. 7/8 (1905), стр. 154-156.

- Женско питање / Ручни рад

220.

БИНГУЛАЦ, Цвета

Крај болесничке постеље / Ц. Б. [Цвета Бингулац] // Год. 20, бр. 11 (1905), стр. 252.

- Књижевност

221.

БИСЕР су сузе / превела с немачког Јелка Прохаска // Год. 20, бр. 7/8 (1905), стр. 183-183.

- Књижевност

222.

БОЖАНСТЕВНА поезија / Хришћанка // Год. 20, бр. 9 (1905), стр. 196.

- Књижевност

223.

БОЖИЋ / с француског Љубомир Лукић // Год. 20, бр. 3 (1905), стр. 57-61. - Књижевност

224.

БОТА, Ђорђе пл. 
Поуке за живот / Ђ. [Ђорђе] пл. Бота // Год. 20, бр. 10 (1905), стр. 224-225.

- Друштвено питање / Савети

225.

БРОНЗИЋ, Драгиња

Дописи / Д. [Драгиња] Бронзићева // Год. 20, бр. 4 (1905), стр. 84.

- Женско питање / Женски покрети

226.

БУТА, Јован Ж.

Сеоске сплетке / Јов. [Јован] Ж. Бута // Год. 20, бр. 7/8 (1905), стр. 174-176.

- Књижевност

227.

ВЕТАР дува / с мађарског М. Новаковић // Год. 20, бр. 10 (1905), стр. 226.

- Књижевност

228.

ВРЕДНЕ руке / „Привредник“// Год. 20, бр. 7/8 (1905), стр. 152-153.

- Женско питање; Педагогија

229.

ГАВРИЛОВИЋ, Миливој М.

Михаилу Ат. Михаиловићу / Миливој М. Гавриловић // Год. 20, бр. 3 (1905), стр. 50.

- Књижевност

230.

ГАВРИЛОВИЋ, Реља

У албум мајци / Реља Гавриловић // Год. 20, бр. 7/8 (1905), стр. 167.

- Књижевност

231.

ГАЈИЋ, Жарко

Вредноме српском композитору / Жарко Гајић // Год. 20, бр. 1 (1905), стр. 11.

- Књижевност

232.

ГАЈИЋ, Жарко

Игра судбине / Жарко Гајић // Год. 20, бр. 1 (1905), стр. 11.

- Књижевност

233.

ГАЈИЋ, Жарко

Једна успомена / Жарко Гајић // Год. 20, бр. 6 (1905), стр. 124.

- Књижевност 
234.

ГАЈИЋ, Жарко

Њој / Жарко Гајић // Год. 20, бр. 9 (1905), стр. 201.

- Књижевност

235.

ГАЈИЋ, Жарко

У свету / Жарко Гајић // Год. 20, бр. 4 (1905), стр. 83.

- Кьижевност

236.

ГЛАСНИК / Б. Ј. Г. // Год. 20, бр. 1 (1905), стр. 19-20.

- Вести

237.

ГЛАСНИК// Год. 20, бр. 2 (1905), стр. 46.

- Вести

238.

ГЛАСНИК // Год. 20, бр. 3 (1905), стр. 66.

- Вести

239.

ГЛАСНИК / Б. Ј. Г. // Год. 20, бр. 4 (1905), стр. 92-94.

- Вести

240.

ГЛАСНИК // Год. 20, бр. 5 (1905), стр. 116-117.

- Вести

241.

ГЛАСНИК // Год. 20, бр. 6 (1905), стр. 140-141.

- Вести

242.

ГЛАСНИК // Год. 20, бр. 9 (1905), стр. 209-211.

- Вести

243.

ГЛАСНИК // Год. 20, бр. 10 (1905), стр. 234-236.

- Вести

244.

ГЛАСНИК // Год. 20, бр. 11 (1905), стр. 259-262.

- Вести 
245.

ГЛАСНИК // Год. 20, бр. 12 (1905), стр. 279-282.

- Вести

246.

ГОСПОЂА Савка дра Јована Суботића // Год. 20, бр. 1 (1905), стр. 8-9.

247.

ГОСПОЂА Савка дра Јована Суботића // Год. 20, бр. 2 (1905), стр. 30-32.

- Вести

248.

ГРГУРОВА, Милка

Сребрн ланац [I] / [Милка Гргурова] // Год. 20, бр. 4 (1905), стр. 85-88.

- Књижевност

249.

ГРГУРОВА, Милка

Сребрн ланац [II] / [Милка Гргурова] // Год. 20, бр. 5 (1905), стр. 108-109.

- Књижевност

250.

ГРГУРОВА, Милка

Сребрн ланац [III] / Милка Гргурова // Год. 20, бр. 6 (1905), стр. 135-138.

- Књижевност

251.

ДВАДЕСЕТПЕТОГОДИШњА прослава // Год. 20, бр. 6 (1905), стр. 126-131.

- Женски покрети

252.

ДВАДЕСЕТПЕТОГОДИШЊА прослава [свршетак] // Год. 20, бр. 7/8 (1905), стр. 168-172.

- Женски покрети

253.

ДВЕ мале девојчице / с мађарског превео М. [Милан] Новаковић // Год. 20, бр. 9 (1905), стр. 207.

- Књижевност

254.

ДИКЛИЋ, Славко С.

У сутону / Славко С. Диклић // Год. 20, бр. 10 (1905), стр. 226.

- Књижевност

255. 
ДИкЛИЋ, Славко С.

Анђео среће / Славко С. Диклић // Год. 20, бр. 1 (1905), стр. 2.

- Књижевност

256.

ДИкЛИЋ, Славко С.

У даљини / Славко С. Диклић // Год. 20, бр. 6 (1905), стр. 123.

- Књижевност

257.

ДО последњег даха / Јова // Год. 20, бр. 5 (1905), стр. 107.

- Књижевност

258.

ДОБРОТВОРНИМ задругама Српкиња на размишљање / М-ћ. // Год. 20, бр. 2 (1905), стр. 25-28.

- Друштвено питање

259.

ДОПИСИ / Анђелија // Год. 20, бр. 3 (1905), стр. 55.

- Женско питање / Женски покрети

260.

ДОПИСИ / Д. // Год. 20, бр. 7/8 (1905), стр. 173-174.

- Вести

261.

ДОПИСИ / М. // Год. 20, бр. 12 (1905), стр. 274-275.

- Вести

262.

ДОПИСИ // Год. 20, бр. 1 (1905), стр. 11-12.

- Вести

263.

ДОПИСИ // Год. 20, бр. 2 (1905), стр. 33-36.

- Вести

264.

ДОПИСИ // Год. 20, бр. 10 (1905), стр. 226-227.

- Вести

265.

ДУША моја // Год. 20, бр. 1 (1905), стр. 18.

- Књижевност 
266.

ЂОНЛИЋ, Анђелија

Два греха / Анђелија Ђонлићева // Год. 20, бр. 10 (1905), стр. 228-231.

- Књижевност

267.

ЂОНЛИЋ, Анђелија

Јесен / Анђелија [Ђонлић] // Год. 20, бр. 12 (1905), стр. 273.

- Књижевност

268.

ЂОНЛИЋ, Анђелија

Славуј и цветак / Анђелија Ђонлић // Год. 20, бр. 4 (1905), стр. 75.

- Књижевност

269.

ЂОНЛИЋ, Анђелија

Спровод / Анђелија Ђонлићева // Год. 20, бр. 11 (1905), стр. 246.

- Књижевност

270.

ЖЕБАР, Емил

О земаљском рају / Емил Жебар ; с француског превео Панајот Анастасијевић // Год. 20, бр. 7/8 (1905), стр. 164-167.

- Књижевност

271.

ЖЕНСКИ шегрти / Велинка // Год. 20, бр. 6 (1905), стр. 121-123.

- Женско питање

272.

ЖЕНСКИ шегрти // Год. 20, бр. 7/8 (1905), стр. 145-150.

- Женско питање / Женски покрети

273.

ЖИВОЈНОВИЋ, Јован

Јесен, лето, пролеће / Ј. Ж. [Јован Живојновић] // Год. 20, бр. 5 (1905), стр. 107.

- Књижевност

274.

ЖИВОЈНОВИЋ, Јован

Књижевност / Јован Живојновић // Год. 20, бр. 7/8 (1905), стр. 191-192.

- Вести / Књижевност

275.

ЖИВОЈНОВИЋ, Јован

На те мислим / Ј. Ж. [Јован Живојновић] // Год. 20, бр. 10 (1905), стр. 221. 
- Књижевност

276.

ЖИВОЈНОВИЋ, Јован

На Ускрс 1905 : (својој Лепосави) / Ј. Ж. [Јован Живојновић] // Год. 20, бр. 5 (1905), стр. 105.

- Књижевност

277.

ЖИВОЈНОВИЋ, Јован

Несретна љубав / Ј. Ж. [Јован Живојновић] // Год. 20, бр. 3 (1905), стр. 56.

- Књижевност

278.

ЖИВОЈНОВИЋ, Јован 193.

Новом Александру Великом / Ј. Ж. [Јован Живојновић] // Год. 20, бр. 9 (1905), стр.

- Књижевност

279.

ЖИВОЈНОВИЋ, Јован

О Крашованима [I] / Говорио о покладном селу у „Српској читаоници“ Ј. Ж. [Јован Живојновић] // Год. 20, бр. 4 (1905), стр. 76-79.

- Друштвено питање

280.

ЖИВОЈНОВИЋ, Јован

О Крашованима [II] / Говорио о покладном селу у „Српској читаоници“ Ј. Ж. [Јован Живојновић] // Год. 20, бр. 5 (1905), стр. 100-104.

- Друштвено питање

281.

ЖИВОЈНОВИЋ, Јован

Онима, који зазиру од „Несретне љубави“ / Ј. Ж. [Јован Живојновић] Год. 20, бр. 4 (1905), стр. 80.

- Књижевност

282.

ЖИВОЈНОВИЋ, Јован

Стаза живота / Ј. Ж. [Јован Живојновић] // Год. 20, бр. 6 (1905), стр. 124.

- Књижевност

283.

ЖУРИ, пожури / Јулија // Год. 20, бр. 11 (1905), стр. 245.

- Књижевност 
284.

ЗА домаћице // Год. 20, бр. 1 (1905), стр. 22.

- Женско питање / Савети

285.

3А домаћице // Год. 20, бр. 2 (1905), стр. 47.

- Женско питање / Савети

286.

ЗА домаћице // Год. 20, бр. 3 (1905), стр. 68.

- Женско питање / Савети

287.

ЗА домаћице // Год. 20, бр. 6 (1905), стр. 143.

- Женско питање / Кућни послови (савети, упутства)

288.

ЗА домаћице // Год. 20, бр. 9 (1905), стр. 215.

- Женско питање / Савети

289.

ЗА домаћице // Год. 20, бр. 12 (1905), стр. 283.

- Женско питање / Савети

290.

ЗАКИЋ, Милорад J.

- Вести

Дописи / Милорад Ј. Закић // Год. 20, бр. 11 (1905), стр. 250-251.

291.

ЗАНИМљИВА свадба у Каиру / Превод Раде Крајиновића // Год. 20, бр. 3 (1905), стр. 57-60.

- Књижевност

292.

ЗДРАВЉЕ // Год. 20, бр. 1 (1905), стр. 22.

- Здравље

293.

ЗДРАВЉЕ // Год. 20, бр. 2 (1905), стр. 47.

- Здравље

294.

ЗДРАВљЕ // Год. 20, бр. 3 (1905), стр. 68.

- Здравље 
295.

ЗДРАВЉЕ // Год. 20, бр. 5 (1905), стр. 118.

- Здравље

296.

ЗДРАВЉЕ // Год. 20, бр. 9 (1905), стр. 215.

- Здравље

297.

ЗДРАВЉЕ // Год. 20, бр. 10 (1905), стр. 238.

- Здравље

298.

ЗОРИЋ, Душан

12 / Душан Зорић // Год. 20, бр. 7/8 (1905), стр. 152-153.

- Књижевност

299.

ИЛАРИОН Руварац 1832-1905 // Год. 20, бр. 9 (1905), стр. 199-200.

- Некролог

300.

ИЛКИЋ, Стеван С.

О васпитању женскиња / говорио Ст. [Стеван] С. Илкић при прослави Крсног Имена Добротворне задруге Српкиња Сомборкиња 1904 // Год. 20, бр. 1 (1905), стр. 3-6.

- Породица / Васпитање

301.

ИСАКОВИЋ, Миливој Ђ.

Њој / Миливој Ђ. Исаковић // Год. 20, бр. 7/8 (1905), стр. 173.

- Књижевност

302.

ЈА те љубим / Јулијана // Год. 20, бр. 7/8 (1905), стр. 160.

- Књижевност

303.

ЈЕСЕН / Јулија // Год. 20, бр. 10 (1905), стр. 225.

- Књижевност

304.

ЈОСИЋ, Младен

Српкињама / Поп Младен Јосић // Год. 20, бр. 5 (1905), стр. 105-106.

- Женско питање / Ручни рад

305. 
КАЛИЋ, Катинка

Пут у Немачку / Катинка Калић // Год. 20, бр. 12 (1905), стр. 268-272.

- Књижевност

306.

КАРАБЕГОВИЋ, Авдо

Мати / Авдо Карабеговић // Год. 20, бр. 7/8 (1905), стр. 154.

- Књижевност

307.

КАРАБЕГОВИЋ, Авдо

У споменицу / Авдо Карабеговић // Год. 20, бр. 7/8 (1905), стр. 161.

- Књижевност

308.

КАРАБЕГОВИЋ, Авдо

Хајде пођи / Авдо Карабеговић // Год. 20, бр. 7/8 (1905), стр. 160.

- Књижевност

309.

КНЕЖЕВИЋ, Јован

Ellen Кеу / Ј. [Јован] Кнежевић // Год. 20, бр. 5 (1905), стр. 98-99.

Биографије

310.

КЊИЖЕВНОСТ // Год. 20, бр. 1 (1905), стр. 22-24.

- Вести / Књижевност

311.

КЊИЖЕВНОСТ // Год. 20, бр. 2 (1905), стр. 47.

- Вести / Књижевност

312.

КЊИЖЕВНОСТ // Год. 20, бр. 3 (1905), стр. 69-71.

- Вести / Књижевност

313.

КЊИЖЕВНОСТ // Год. 20, бр. 4 (1905), стр. 95.

- Вести / Књижевност

314.

КЊИЖЕВНОСТ // Год. 20, бр. 6 (1905), стр. 143.

- Вести / Књижевност

315.

КЊИЖЕВНОСТ // Год. 20, бр. 9 (1905), стр. 215-216. 
- Вести / Књижевност

316.

КЊИЖЕВНОСТ // Год. 20, бр. 10 (1905), стр. 239-240.

- Вести / Књижевност

317.

КРАГУЉЕВИЋ, Милош П.

Мој идеал / Милош П. Крагуљевић // Год. 20, бр. 10 (1905), стр. 224.

- Књижевност

318.

КРАГУљЕВИЋ, Милош П. 106.

Над гробом моје кћери Данице / Милош П. Крагуљевић // Год. 20, бр. 5 (1905), стр.

- Књижевност

319.

КРСТИЋ, Анђелија М.

Сан на селу / Анђ. [Анђелија] М. Крстић // Год. 20, бр. 7/8 (1905), стр. 156.

- Књижевност

320.

КРСТИЋ, Васа

Пружаш ми белу руку /-булбуц. // Год. 20, бр. 7/8 (1905), стр. 154.

- Књижевност

321.

ЛЕЧЕЊЕ помоћу својих мисли / с немачког Ђорђе пл. Бота // Год. 20, бр. 7/8 (1905), стр. 160.

- Здравље

322.

ЛОНЧАР-Трбојевић, Драга

Мај је био... да л' се сећаш? / Драг. [Драга] Лончар-Трбојевић // Год. 20, бр. 12 (1905), стр. 275.

- Књижевност

323.

ЛОНЧАР-Трбојевић, Драга

Мојој срећи / Драга Лончар-Трбојевић // Год. 20, бр. 5 (1905), стр. 99.

- Књижевност

324.

ЛОНЧАР-Трбојевић, Драга

Мојој срећи / Драг. [Драга] Лончар-Трбојевић // Год. 20, бр. 10 (1905), стр. 222. 
- Књижевност

325.

ЛОНЧАР-Трбојевић, Драга

Над гробом / Драга Лончар-Трбојевић // Год. 20, бр. 7/8 (1905), стр. 157.

- Књижевност

326.

ЛУЊЕВИЦА, Влада М.

Вешт уметник / Влада М. Луњевица // Год. 20, бр. 11 (1905), стр. 244.

- Књижевност

327.

ЛУЊЕВИЦА, Влада М.

Звонар / Влада М. Луњевица // Год. 20, бр. 9 (1905), стр. 199.

- Књижевност

328.

ЛУЊЕВИЦА, Влада М.

Један пут ме нашла нада / Влада М. Луњевица // Год. 20, бр. 11 (1905), стр. 250.

- Књижевност

329.

ЛУЊЕВИЦА, Влада М.

Јесења туга / Влада М. Луњевица // Год. 20, бр. 11 (1905), стр. 246.

- Књижевност

330.

ЛУЊЕВИЦА, Влада М.

Крај ковчега / Влада М. Луњевица // Год. 20, бр. 7/8 (1905), стр. 151.

- Књижевност

331.

ЛУЊЕВИЦА, Влада М.

Моја прва љубав / Влад. [Влада] М. Луњевица // Год. 20, бр. 1 (1905), стр. 13-18.

- Књижевност

332.

ЛУЊЕВИЦА, Влада М.

Непознатој / Влада М. Луњевица // Год. 20, бр. 6 (1905), стр. 131.

- Књижевност

333.

МАЈСКА ружа / с мађарског М. [Милан] Новаковић // Год. 20, бр. 6 (1905), стр. 134.

- Књижевност 
334.

МАЈСТОРОВИЋ, $\mathrm{H}$.

Говор тајника „Добротворне задруге Српкиња у Госпићу“ г. професора-катихете Н. Мајсторовића / [Н. Мајсторовић] // Год. 20, бр. 12 (1905), стр. 266-267.

- Женско питање / Женски покрети

335.

МЕЂУ Лужичким Србима : писма гђе Савке дра Ј. Суботића [I] // Год. 20, бр. 10 (1905), стр. 217-220.

- Друштвено питање

336.

МЕЂУ Лужичким Србима : писма гђе Савке дра Ј. Суботића [II] // Год. 20, бр. 11 (1905), стр. 241-244.

- Друштвено питање

337.

МИЛАНОВИЋ, Радован

Мајка / Радован Милановић // Год. 20, бр. 5 (1905), стр. 104.

- Књижевност

338.

МИЛОСРЂЕ : Божићна приповетка / превео Душан // Год. 20, бр. 12 (1905), стр. 276278.

- Књижевност

339.

МИЛОСТИҢА / превод Раде Крајиновића // Год. 20, бр. 7/8 (1905), стр. 179-183.

- Књижевност

340.

МИТРОВИЋ, Исаије

Ах та све... све заборави! / Исаије Митровић // Год. 20, бр. 3 (1905), стр. 57.

- Књижевност

341.

МИТРОВИЋ, Исаије

Муко моја зверко гладна / Исаије Митровић // Год. 20, бр. 11 (1905), стр. 251.

- Књижевност

342.

МИТРОВИЋ, Исаије

Опроштај / Исаије Митровић // Год. 20, бр. 7/8 (1905), стр. 162.

- Књижевност

343.

МИТРОВИЋ, Исаије 
Остај овде / Исаије Митровић // Год. 20, бр. 7/8 (1905), стр. 164.

- Књижевност

344.

МИТРОВИЋ, Исаије

Пролеће је / Исаије Митровић // Год. 20, бр. 6 (1905), стр. 126.

- Књижевност

345.

МИТРОВИЋ, Исаије

Славонски мотиви / Исаије Митровић // Год. 20, бр. 11 (1905), стр. 247.

- Књижевност

346.

МОЈА слабост / Томир // Год. 20, бр. 2 (1905), стр. 29.

- Књижевност

347.

НА мајчином гробу / Севаст. Јовановић // Год. 20, бр. 4 (1905), стр. 79.

- Књижевност

348.

НА прагу двадесете // Год. 20, бр. 1 (1905), стр. 1-2.

- Друштвено питање

349.

НАУЧНА женска удружења // Год. 20, бр. 12 (1905), стр. 265-266.

- Женско питање / Женски покрети

350.

НАШЕ задруге Српкиња и шегрти // Год. 20, бр. 3 (1905), стр. 49-50.

- Женско питање / Женски покрети

351.

НАШИ заводи за више женско образовање // Год. 20, бр. 9 (1905), стр. 1494-195.

- Женско питање; Образовање

352.

НЕКАД и сад / Јова // Год. 20, бр. 7/8 (1905), стр. 156.

- Књижевност

353.

НЕРАНЏИЋ-Брашован, Даринка

Божанствена поезија / Д. [Даринка] Неранџић-Брашованова // Год. 20, бр. 1 (1905), стр. 3.

- Књижевност 
354.

НЕЋУ те клети / Драга // Год. 20, бр. 1 (1905), стр. 12.

- Књижевност

355.

НИКОЛИЋ, Александар М.

Њој / Ал. М. Ник. [Александар М. Николић] // Год. 20, бр. 4 (1905), стр. 80.

- Књижевност

356.

НИКОЛИЋ, Александар М.

Развејано лишће / Ал. М. Ник. [Александар М. Николић]. - Садржи песме:

Изгубљеној, Тужан дан, Истог дана // Год. 20, бр. 7/8 (1905), стр. 168.

- Књижевност

357.

НОВАКОВИЋ, Милан

Звезда / М. [Милан] Новаковић // Год. 20, бр. 9 (1905), стр. 207.

- Књижевност

358.

НОВИНАРСТВО // Год. 20, бр. 5 (1905), стр. 119.

- Вести

359. 244.

ЊОЈ / спјевао Рудолф барун Малдини Вилденхајнски // Год. 20, бр. 11 (1905), стр.

- Књижевност

360.

ОН је будала // Год. 20, бр. 10 (1905), стр. 231-233.

- Књижевност

361.

$\mathrm{OH}$ је будала : шала у једном чину од Моргендера : (свршетак) / превела Христина А. Пурића // Год. 20, бр. 11 (1905), стр. 254-259.

- Књижевност

362.

ОТАЦ Ричардо : прича са Кубе / превео Раде Крајиновић // Год. 20, бр. 9 (1905), стр. 202-205.

- Књижевност

363.

ПЕШИЋ, Лазар 
Душа ме боли / Лазар Пешић Јованов // Год. 20, бр. 12 (1905), стр. 268.

- Књижевност

364.

ПЕШИЋ, Лазар

Њу ми траже / Лазар Пешић Јованов // Год. 20, бр. 12 (1905), стр. 268.

- Књижевност

365.

ПЕШИЋ, Лазар

Српска мајка са Косова / Лазар Пешић Јованов // Год. 20, бр. 7/8 (1905), стр. 161.

- Кьижевност

366.

ПИЈЕТРОВА, Светлана

Где сте... / Светлана Пијетрова // Год. 20, бр. 3 (1905), стр. 50.

- Књижевност

367.

ПИЈЕТРОВА, Светлана

Тешко ми је... / Светлана Пијетрова // Год. 20, бр. 4 (1905), стр. 75.

- Књижевност

368.

ПИСМА из Београда : I / Шумадинка // Год. 20, бр. 1 (1905), стр. 7-8.

- Друштвено питање

369.

ПИСМА из Београда : II / Шумадинка // Год. 20, бр. 2 (1905), стр. 29.

- Друштвено питање

370.

ПИСМА из Београда : III / Шумадинка // Год. 20, бр. 3 (1905), стр. 52-53.

- Друштвено питање

371.

ПОЗДРАВИ Гђи Савки дра Ј. Суботића // Год. 20, бр. 4 (1905), стр. 83.

- Вести

372.

ПОКАЈАЛА се / превео Душан // Год. 20, бр. 11 (1905), стр. 252-254.

- Књижевност

373.

ПОКАЈНИЦА / Јова // Год. 20, бр. 10 (1905), стр. 221.

- Књижевност 
374.

ПОљУБАЦ / Томир // Год. 20, бр. 1 (1905), стр. 18.

- Књижевност

375.

ПОПОВИЋ, Јово Г.

Владичин гроб / Јово Г. Поповић // Год. 20, бр. 7/8 (1905), стр. 161.

- Књижевност

376.

ПОПОВИЋ, Јово Г.

Јесења песма / Јово Г. Поповић // Год. 20, бр. 11 (1905), стр. 246.

- Књижевност

377.

ПОПОВИЋ, Јово Г.

Кликовање / Јово Г. Поповић // Год. 20, бр. 11 (1905), стр. 249.

- Књижевност

378.

ПОПОВИЋ, Јово Г.

Крвава ријека / Јово Г. Поповић-Босанац // Год. 20, бр. 3 (1905), стр. 52.

- Књижевност

379.

ПОПОВИЋ, Јово Г.

Поздрав Скопљу / Јово Поповић // Год. 20, бр. 7/8 (1905), стр. 151.

- Књижевност

380.

ПОПОВИЋ, Јово Г.

Свиће зора / Јово Г. Поповић-Босанац // Год. 20, бр. 4 (1905), стр. 83.

- Књижевност

381.

ПОПОВИЋ, Јово Г.

Скопско декле / Јово Поповић // Год. 20, бр. 7/8 (1905), стр. 150.

- Књижевност

382.

ПОПОВИЋ, Марко С.

Свечани говор / Говорио Поп Марко С. Поповић // Год. 20, бр. 3 (1905), стр. 51-52.

- Друштвено питање

383. 
ПОСЛЕДЊА љубичица / Вукица Вуканова // Год. 20, бр. 7/8 (1905), стр. 176-179.

- Књижевност

384.

ПОУЗДАНИК Орбасан / с немачког превела Violetta Garibaldi // Год. 20, бр. 2 (1905), стр. 37-43.

- Књижевност

385.

ПОУКЕ за живот / с немачког Ђ. [Ђорђе] пл. Бота // Год. 20, бр. 11 (1905), стр. 248249.

- Друштвено питање / Савети

386.

ПОУКЕ за живот / с немачког Ђ. [Ђорђе] пл. Бота // Год. 20, бр. 12 (1905), стр. 273274.

- Друштвено питање / Савети

387.

ПРОСВЕТА // Год. 20, бр. 1 (1905), стр. 22.

- Образовање / Педагогија

388.

ПРОСВЕТА // Год. 20, бр. 2 (1905), стр. 46.

- Образовање

389.

ПРОСВЕТА // Год. 20, бр. 3 (1905), стр. 67-68.

- Образовање

390.

ПРОСВЕТА // Год. 20, бр. 4 (1905), стр. 95.

- Образовање / Педагогија

391.

ПРОСВЕТА // Год. 20, бр. 5 (1905), стр. 118.

- Образовање

392.

ПРОСВЕТА // Год. 20, бр. 6 (1905), стр. 142-143.

- Образовање

393.

ПРОСВЕТА // Год. 20, бр. 7/8 (1905), стр. 190-191.

- Образовање 
394.

ПРОСВЕТА // Год. 20, бр. 9 (1905), стр. 214-215.

- Образовање

395.

ПРОСВЕТА // Год. 20, бр. 10 (1905), стр. 238.

- Образовање

396.

ПРОСВЕТА // Год. 20, бр. 11 (1905), стр. 263.

- Образовање

397.

ПРОСВЕТА // Год. 20, бр. 12 (1905), стр. 283

- Образовање

398.

РАД добротворних задруга Српкиња // Год. 20, бр. 2 (1905), стр. 44.

- Женско питање / Женски покрети

399.

РАД добротворних задруга Српкиња // Год. 20, бр. 3 (1905), стр. 61-64.

- Женско питање / Женски покрети

400.

РАД добротворних задруга Српкиња // Год. 20, бр. 4 (1905), стр. 88-92.

- Женско питање / Женски покрети

401.

РАД добротворних задруга Српкиња // Год. 20, бр. 5 (1905), стр. 111-116.

- Женско питање / Женски покрети

402.

РАД добротворних задруга Српкиња / П. // Год. 20, бр. 6 (1905), стр. 138-140.

- Женско питање / Женски покрети

403.

РАД добротворних задруга Српкиња // Год. 20, бр. 7/8 (1905), стр. 185-189.

- Женско питање / Женски покрети

404.

РАД добротворних задруга Српкиња // Год. 20, бр. 9 (1905), стр. 207-209.

- Женско питање / Женски покрети

405.

РАД добротворних задруга Српкиња // Год. 20, бр. 10 (1905), стр. 234. 
- Женско питање / Женски покрети

406.

РАД добротворних задруга Српкиња // Год. 20, бр. 12 (1905), стр. 278.

- Женско питање / Женски покрети

407.

РАДАК, Јефта

Жеље / J. Р-к. [Јефта Радак] // Год. 20, бр. 3 (1905), стр. 50.

- Књижевност

408.

РАДАК, Јефта

У споменицу / J. Р-к. [Јефта Радак] // Год. 20, бр. 10 (1905), стр. 226.

- Књижевност

409.

РАЗНО // Год. 20, бр. 1 (1905), стр. 22.

- Породица / Савети

410.

РАЗНО // Год. 20, бр. 2 (1905), стр. 47.

- Женско питање / Женски покрети

411.

РАЗНО // Год. 20, бр. 3 (1905), стр. 68-69.

- Вести

412.

РАЗНО // Год. 20, бр. 5 (1905), стр. 118-119.

- Женско питање

413.

РАЗНО // Год. 20, бр. 9 (1905), стр. 215.

- Вести

414.

РАЗНО // Год. 20, бр. 10 (1905), стр. 239.

- Вести

415.

РАЗНО // Год. 20, бр. 12 (1905), стр. 283.

- Женско питање / Вести

416. 
РАСПОРЕД двадесетпетогодишње прославе Добротворне здруге Српкиње Новосаткиње // Год. 20, бр. 5 (1905), стр. 98.

- Женски покрети

417.

РАШИЋ, Јулка

Милки Марковићки / Јулка Р. [Рашић] // Год. 20, бр. 1 (1905), стр. 6.

- Књижевност

418.

СЕСТРА Перегрина / Г. // Год. 20, бр. 5 (1905), стр. 109-111.

- Књижевност

419.

СЕЋАЋУ се // Год. 20, бр. 2 (1905), стр. 37.

- Књижевност

420.

СИМБОЛИКА цвећа и говор цвећа / с немачког Ђ. [Ђорђе] пл. Бота // Год. 20, бр. 9 (1905), стр. 1496-198.

421.

СРБИЈА // Год. 20, бр. 1 (1905), стр. 22.

- Образовање

422.

СРПСКО привредно друштво „Привредник“ // Год. 20, бр. 11 (1905), стр. 245-.246

- Друштвено питање

423.

СТАРЧЕВИЋ, Пава

Писмо свима српским ратарским девојкама / Пава кћи Шандора Старчевића // Год. 20, бр. 4 (1905), стр. 82.

- Друштвено питање

424.

СТЕФАНОВИЋ, ОЛга

Дописи / Олга Стефановић // Год. 20, бр. 6 (1905), стр. 131-134.

- Вести

425.

СТОЛПОВИЋ, Драгомир Е.

Два греха / Драг. [Драгомир] Е. Столповић // Год. 20, бр. 10 (1905), стр. 228.

- Књижевност

426. 
СТОЛПОВИЋ, Драгомир Е.

Дописи / Драгомир Е. Столповић // Год. 20, бр. 9 (1905), стр. 201-202.

- Женско питање

427.

СУБОТИЋ, Савка

Јавна благодарност / Савка Ј. Суботић // Год. 20, бр. 2 (1905), стр. 32-33.

- Вести

428.

ТВОЈА суза / Јова // Год. 20, бр. 10 (1905), стр. 228.

- Књижевност

429.

ТВОЈЕ очи / Јова // Год. 20, бр. 4 (1905), стр. 84.

- Књижевност

430. 168.

ТЕОРЕТИЧНО кување / са мађарског превела Т. // Год. 20, бр. 7/8 (1905), стр. 167-

- Књижевност

431.

ТО си ти / Јова // Год. 20, бр. 2 (1905), стр. 43.

- Књижевност

432.

ТРИДЕСЕТОГОДИШњА прослава Женског друштва у Београду

- Женски покрети

433.

ТРИФУНОВИЋ, Милан М.

Благо мени / Милан М. Трифуновић // Год. 20, бр. 11 (1905), стр. 251.

- Књижевност

434.

У маленом сеоцету... / 3. // Год. 20, бр. 2 (1905), стр. 28.

- Књижевност

435.

ХОЛЕЦОВА, Катарина

Читуља / Кат. [Катарина] Холецова // Год. 20, бр. 1 (1905), стр. 20-21.

- Вести / Некролог

436.

ЦРТИЦЕ за живот // Год. 20, бр. 7/8 (1905), стр. 162-164. 
- Друштвено питање

437.

ЧИТУљА // Год. 20, бр. 2 (1905), стр. 46.

- Вести / Некролог

438.

ЧИТУљА // Год. 20, бр. 3 (1905), стр. 66-67.

- Вести / Некролог

439.

ЧИТУЉА // Год. 20, бр. 4 (1905), стр. 94.

- Вести / Некролог

440.

ЧИТУљА // Год. 20, бр. 5 (1905), стр. 118.

- Вести / Некролог

441.

ЧИТУљА // Год. 20, бр. 6 (1905), стр. 141-142.

- Вести / Некролог

442.

ЧИТУљА // Год. 20, бр. 7/8 (1905), стр. 189-190.

- Вести / Некролог

443.

ЧИТУљА // Год. 20, бр. 9 (1905), стр. 211-213.

- Вести / Некролог

444.

ЧИТУљА // Год. 20, бр. 10 (1905), стр. 237.

- Вести / Некролог

445.

ЧИТУљА // Год. 20, бр. 11 (1905), стр. 262-263.

- Вести / Некролог

446.

ЧИТУљА // Год. 20, бр. 12 (1905), стр. 282-283.

- Вести / Некролог

447.

ШАТОРИ, Етелка

Какав хлеб треба да једемо / написала Етелка Шатори ; превео А. М. // Год. 20, бр. 10 (1905), стр. 222-224. 
- Здравље 


\section{6.}

448.

АВРАМОВИЋ, Милан Ј.

Заборавиће се / Мил. [Милан] Ј. Аврамовић // Год. 21, бр. 12 (1906), стр. 271-273.

- Књижевност

449.

БАНДИЋ, Даница

Прва љубав / Даница Бандић // Год. 21, бр. 4 (1906), стр. 83-84.

- Књижевност

450.

БАНДИЋ, Љубица

Чудотворна икона / Љубица Бандић // Год. 21, бр. 1 (1906), стр. 14-16.

- Књижевност

451.

БЕЛОВИЋ, Јелица

Наша везиљачка народна умјетност / Јелица Беловић // Год. 21, бр. 1 (1906), стр. 6-7.

- Женско питање / Ручни рад

452.

БЕЛОВИЋ, Јелица

Наша народна ношња / Јелица Беловићева // Год. 21, бр. 8 (1906), стр. 171-172.

- Женско питање / Ношња

453.

БЕЛОВИЋ, Јелица

О важности везења народне торбице / пише Јелица Беловићева // Год. 21, бр. 3 (1906), стр. 55-56.

- Женско питање / Ручни рад

454.

БОЖАНСТВЕНА поезија / Хришћанка // Год. 21, бр. 11 (1906), стр. 243.

- Књижевност

455.

БОТА, Ђорђе пл.

Анегдоте из живота / Ђ. [Ђорђе] пл. Бота // Год. 21, бр. 6 (1906), стр. 124-126.

- Друштвено питање / Савети

456.

БУРА у породици / Cordelia ; с талијанског Бранислав С. Кирић // Год. 21, бр. 8 (1906), стр. 180-183. 
- Књижевност

457.

БУТА, Јован Ж.

Одбеглица / Јов. [Јован] Ж. Бута // Год. 21, бр. 12 (1906), стр. 273-274.

- Књижевност

458.

БУТА, Јован Ж.

Прича једне ластавице / Јован Ж. Бута // Год. 21, бр. 9 (1906), стр. 207-209.

- Књижевност

459.

ВОДА за купање малог детета / Ј. Б. // Год. 21, бр. 12 (1906), стр. 269-270

- Здравље

460.

ГАВРИЛОВИЋ, Миливој

Бор. Л. Ценићу / М. [Миливој] М. Гавриловић // Год. 21, бр. 9 (1906), стр. 198.

- Књижевност

461.

ГАВРИЛОВИЋ, Миливој

Мој зумбуле / М. [Миливој] М. Гавриловић // Год. 21, бр. 10 (1906), стр. 221.

- Књижевност

462.

ГАВРИЛОВИЋ, Миливој

У ђул-башти / М. [Миливој] М. Гавриловић // Год. 21, бр. 7 (1906), стр. 159.

- Књижевност

463.

ГАЈИЋ, Жарко

Материна туга / Жарко Гајић // Год. 21, бр. 5 (1906), стр. 103.

- Књижевност

464.

ГАЈИЋ, Жарко

Моме анђелу / Жарко Гајић // Год. 21, бр. 2 (1906), стр. 38.

- Књижевност

465.

ГАЈИЋ, Жарко

Цвети / Жарко Гајић // Год. 21, бр. 4 (1906), стр. 76.

- Књижевност 
466.

ГЛАСНИК // Год. 21, бр. 1 (1906), стр. 17-18.

- Вести

467.

ГЛАСНИК // Год. 21, бр. 2 (1906), стр. 39-40.

- Вести

468.

ГЛАСНИК // Год. 21, бр. 3 (1906), стр. 67-68.

- Вести

469.

- Вести

ГЛАСНИК // Год. 21, бр. 4 (1906), стр. 91-92.

470.

ГЛАСНИК // Год. 21, бр. 5 (1906), стр. 115-116.

- Вести

471.

ГЛАСНИК // Год. 21, бр. 6 (1906), стр. 138-140.

- Вести

472.

ГЛАСНИК // Год. 21, бр. 7 (1906), стр. 161-162.

- Вести

473.

ГЛАСНИК // Год. 21, бр. 8 (1906), стр. 186-188.

- Вести

474.

ГЛАСНИК // Год. 21, бр. 9 (1906), стр. 210-211.

- Вести

475.

- Вести

ГЛАСНИК // Год. 21, бр. 10 (1906), стр. 235-237.

476.

ГЛАСНИК // Год. 21, бр. 11 (1906), стр. 254-255.

- Вести

477.

ГЛАСНИК // Год. 21, бр. 12 (1906), стр. 277-279. 
- Вести

478.

ГОСПОЂИ О. К. / Мира // Год. 21, бр. 5 (1906), стр. 107.

- Књижевност

479.

ГОСПОЂИ Савки Суботићки : посвећено за рођендан / Јелица // Год. 21, бр. 10 (1906), стр. 219.

- Књижевност

480.

ГРГУРОВА, Милка

Добрила [I] / Милка Гргурова // Год. 21, бр. 4 (1906), стр. 84-86.

- Књижевност

481.

ГРГУРОВА, Милка

Добрила [II] / Милка Гргурова // Год. 21, бр. 5 (1906), стр. 107-112.

- Књижевност

482.

ДИКЛИЋ, Славко С.

Јутро / Славко С. Диклић // Год. 21, бр. 1 (1906), стр. 8.

- Књижевност

483.

ДИкЛИЋ, Славко С.

Кад живот цео / Славко С. Диклић // Год. 21, бр. 8 (1906), стр. 178.

- Књижевност

484.

ДИкЛИЋ, Славко С.

На самртном одру једног девојчета / Славко С. Диклић // Год. 21, бр. 3 (1906), стр. 56.

- Књижевност

485.

ДИКЛИЋ, Славко С.

Очекивање / Славко С. Диклић // Год. 21, бр. 8 (1906), стр. 172.

- Књижевност

486.

ДИКЛИЋ, Славко С.

Песма другу / Славко С. Диклић // Год. 21, бр. 8 (1906), стр. 177.

- Књижевност 
487.

ДИКЛИЋ, Славко С.

Ти би чдо / Славко Диклић // Год. 21, бр. 7 (1906), стр. 149.

- Књижевност

488.

ДИКЛИЋ, Славко С.

У шумарку / Славко С. Диклић // Год. 21, бр. 2 (1906), стр. 32.

- Књижевност

489.

ДОБРА дела патријарха Георгија // Год. 21, бр. 1 (1906), стр. 1-2.

- Друштвено питање

490.

ДОБРОТВОРНИМ нашим задругама и осталим Српкињама // Год. 21, бр. 6 (1906), стр. 121-122.

- Женско питање / Женски покрети

491.

ДОПИСИ / Д. Б-ћ. // Год. 21, бр. 6 (1906), стр. 128.

- Вести

492.

ДОПИСИ / Д. К. // Год. 21, бр. 1 (1906), стр. 12-13.

- Вести

493.

ДОПИСИ / Ј. Г. П // Год. 21, бр. 11 (1906), стр. 245-246.

- Друштвено питање

494.

ДОПИСИ // Год. 21, бр. 2 (1906), стр. 33-35.

- Вести

495.

ДОПИСИ // Год. 21, бр. 3 (1906), стр. 56-58.

- Вести

496.

ДОПИСИ // Год. 21, бр. 4 (1906), стр. 81-82.

- Вести

497.

ДОПИСИ // Год. 21, бр. 8 (1906), стр. 178-180.

- Вести 
498.

ДОПИСИ // Год. 21, бр. 10 (1906), стр. 230-232.

- Женско питање / Женски покрети

499.

ЂОНЛИЋ, Анђелија

Ајша / Анђелија Ђонлићева // Год. 21, бр. 3 (1906), стр. 59-61.

- Књижевност

500.

ЂОНЛИЋ, Анђелија

Другарице / Анђелија Ђонлићева // Год. 21, бр. 6 (1906), стр. 129-132.

- Књижевност

501.

ЂОНЛИЋ, Анђелија

Зимска ноћ / Анђелија [Ђонлић] // Год. 21, бр. 2 (1906), стр. 32.

- Књижевност

502.

ЂОНЛИЋ, Анђелија

Лаку ноћ / Анђелија Ђонлићева // Год. 21, бр. 4 (1906), стр. 83.

- Књижевност

503.

ЂОНЛИЋ, Анђелија

Мајци / Анђелија [Ђонлић] // Год. 21, бр. 6 (1906), стр. 129.

- Књижевност

504.

ЂУРОШЕВИЋ, Младен

Даље образовање девојака у Немачкој / Мл. [Младен] Ђурошевић // Год. 21, бр. 12 (1906), стр. 265-268.

- Женско питање / Образовање

505.

ЕТЕЛКА, Шатор

О неговању и васпитању деце / Шатор Етелка ; превео А. Мародић // Год. 21, бр. 10 (1906), стр. 223-226.

- Женско питање / Васпитање

506.

ЖЕНСКА удружења у Срба // Год. 21, бр. 3 (1906), стр. 49-52.

- Женско питање / Женски покрети 
507.

ЖЕНСКИЬЕ у борби за изборним правом // Год. 21, бр. 1 (1906), стр. 7

- Женско питање / Права

508.

ЖИВОЈНОВИЋ, Јован

Свиларска радиност / Ј. Ж. [Јован Живојновић] // Год. 21, бр. 4 (1906), стр. $73-76$.

- Друштвено питање

509.

ЗА домаћице // Год. 21, бр. 1 (1906), стр. 20-21.

- Женско питање / Савети

510.

ЗА домаћице // Год. 21, бр. 2 (1906), стр. 43.

- Женско питање / Савети

511.

ЗА домаћице // Год. 21, бр. 4 (1906), стр. 93.

- Женско питање / Савети

512.

ЗА домаћице // Год. 21, бр. 5 (1906), стр. 117.

- Женско питање / Савети

513.

ЗА домаћице // Год. 21, бр. 6 (1906), стр. 142.

- Женско питање / Савети

514.

ЗА домаћице // Год. 21, бр. 7 (1906), стр. 164.

- Женско питање / Савети

515.

ЗА домаћице // Год. 21, бр. 9 (1906), стр. 213.

- Женско питање / Савети

516.

ЗА домаћице // Год. 21, бр. 11 (1906), стр. 260.

- Женско питање / Савети

517.

ЗА домаћице // Год. 21, бр. 12 (1906), стр. 281.

- Женско питање / Савети

518. 
ЗДРАВЉЕ // Год. 21, бр. 1 (1906), стр. 20.

- Здравље

519.

ЗДРАВЉЕ // Год. 21, бр. 3 (1906), стр. 69.

- Здравље

520.

ЗДРАВЉЕ // Год. 21, бр. 4 (1906), стр. 92-93.

- Здравље

521.

ЗЕБИЋ Горски, Стеван

Здраво / Стеван Зебић Горски // Год. 21, бр. 11 (1906), стр. 244.

- Књижевност

522.

ЗМАЈУ чика Јови / Вукосава // Год. 21, бр. 1 (1906), стр. 17.

- Књижевност

523.

ЗОРИЋ, Душан

Л'јепо ли је уранити / Душан Зорић // Год. 21, бр. 7 (1906), стр. 159.

- Књижевност

524.

ИВАНИЋ, Делфа

Коло српских сестара / Делфа Ив. Иванићка // Год. 21, бр. 1 (1906), стр. 4-6.

- Женско питање / Женски покрети

525.

ИВАНИЋ, Иван

По околини Душанова Сереза у Маћедонији : из путописа Ивана Иванића / Иван Иванић // Год. 21, бр. 5 (1906), стр. 100-102.

- Друштвено питање

526.

ИВАНИШЕВИЋ, Мило

Успомена / Мило Иванишевић // Год. 21, бр. 6 (1906), стр. 129.

- Књижевност

527.

ИЗ живота знаменитих жена : Нинон де Ланкло / превео Раде Крајиновић // Год. 21, бр. 10 (1906), стр. 232-235.

- Женско питање / Биографије 
528.

ИЛИЋ, Никола

Љубав и мржња / Ник [Никола] Х. Илић // Год. 21, бр. 7 (1906), стр. 158-159.

- Књижевност

529.

ИЛКИЋ, Стеван С.

Говор : о положају женскиња у хришћанству и ван хришћанства [I] / Ст. [Стеван] С. Илкић // Год. 21, бр. 4 (1906), стр. 76-80.

- Женско питање / Положај жена

530.

ИЛКИЋ, Стеван С.

Говор : о положају женскиња у хришћанству и ван хришћанства [II] / Ст. [Стеван] C. Илкић // Год. 21, бр. 5 (1906), стр. 103-105.

- Женско питање / Положај жена

531.

ИСКИДАНИ листићи / -а -к // Год. 21, бр. 10 (1906), стр. 222-223.

- Књижевност

532.

ИСТИНА о несуђеној редничкој школи у Митровици // Год. 21, бр. 7 (1906), стр. 149-151.

- Друштвено питање

533. 227.

ЈЕСЕНСКА ноћ : пријатељу Исаију Митровићу / Атлета // Год. 21, бр. 10 (1906), стр.

- Књижевност

534.

ЈОВАН Стерија Поповић // Год. 21, бр. 10 (1906), стр. 217-218.

- Биографије

535.

ЈОКСИМОВИЋ, Хран. М.

Разно / Хра. М. Јоксимовић // Год. 21, бр. 8 (1906), стр. 189-190.

- Женско питање / Накит

536.

КАЛИЋ, Катинка

Успомене с пута у купалишта / Катинка Калић // Год. 21, бр. 10 (1906), стр. 227-230.

- Књижевност

537. 
КАРАБЕГОВИЋ, Авдо

Оставте ме / Авдо Карабеговић // Год. 21, бр. 12 (1906), стр. 276.

- Књижевност

538.

КЕМПФ, Бранко

Живет' сам хтео / Бранко Кемпф // Год. 21, бр. 6 (1906), стр. 127.

- Књижевност

539.

КЕМПФ, Бранко

Плови, душо! / Бранко Кемпф // Год. 21, бр. 4 (1906), стр. 90.

- Књижевност

540.

КЕМПФ, Бранко

[У црној ноћи...] / Бранко Кемпф // Год. 21, бр. 5 (1906), стр. 99.

- Књижевност

541.

КЊИЖЕВНОСТ // Год. 21, бр. 1 (1906), стр. 21-22.

- Вести / Књижевност

542.

КЬИЖЕВНОСТ // Год. 21, бр. 2 (1906), стр. 44.

- Вести / Књижевност

543.

КЊИЖЕВНОСТ // Год. 21, бр. 3 (1906), стр. 69-70.

- Вести / Књижевност

544.

КЬИЖЕВНОСТ // Год. 21, бр. 4 (1906), стр. 93-94.

- Вести / Књижевност

545.

КЊИЖЕВНОСТ // Год. 21, бр. 5 (1906), стр. 117-118.

- Вести / Књижевност

546.

КНИЖЕВНОСТ // Год. 21, бр. 6 (1906), стр. 142.

- Вести / Књижевност

547.

КЊИЖЕВНОСТ // Год. 21, бр. 7 (1906), стр. 165-166.

- Вести / Књижевност 
548.

КЊИЖЕВНОСТ // Год. 21, бр. 8 (1906), стр. 190.

- Вести / Књижевност

549.

КЊИЖЕВНОСТ // Год. 21, бр. 9 (1906), стр. 213-214.

- Вести / Књижевност

550.

КЊИЖЕВНОСТ // Год. 21, бр. 10 (1906), стр. 238.

- Вести / Књижевност

551.

КњИЖЕВНОСТ // Год. 21, бр. 11 (1906), стр. 281.

- Вести / Књижевност

552.

КЊИЖЕВНОСТ // Год. 21, бр. 12 (1906), стр. 281.

- Вести / Књижевност

553.

КОЊЕВИЋ, Јелена

Како да васпитавамо и образујемо нашу децу : (мисли једне српске матере) / J. К. [Јелена Коњевић] // Год. 21, бр. 7 (1906), стр. 145-149.

- Женско питање / Васпитање

554.

КОСИЋ, Славко М.

У дубрави / Сл. [Славко] М. Косић // Год. 21, бр. 12 (1906), стр. 269.

- Књижевност

555.

КОСТИЋ, Олга

Милици Стојадиновић / О. К. [Олга Костић] // Год. 21, бр. 2 (1906), стр. 31.

- Књижевност

556.

КОШУТИЋ, Анто

Уздаси / [Анто] Кошутић. - Садржи песме: Наступило..., Сан, Плачи срце моје, Да л' се сјећаш? // Год. 21, бр. 1 (1906), стр. 8

- Књижевност

557.

КРАГУЉЕВИЋ, Милош П.

Моје цвијеће / Милош П. Крагуљевић // Год. 21, бр. 2 (1906), стр. 29. 
- Књижевност

558.

КРСТИЋ, Васа

Лице и наличје / Др. Казбулбуц // Год. 21, бр. 12 (1906), стр. 274.

- Књижевност

559.

ЛОНЧАР-Трбојевић, Драга

Мајска ноћ / Драг. [Драга] Лончар-Трбојевић // Год. 21, бр. 7 (1906), стр. 149.

- Књижевност

560.

ЛОНЧАР-Трбојевић, Драга

Молитва! / Драг. [Драга] Лончар-Трбојевић // Год. 21, бр. 4 (1906), стр. 81.

- Књижевност

561.

ЛОНЧАР-Трбојевић, Драга

Сјени моје мале Олгице / Драг. [Драга] Лончар-Трбојевић // Год. 21, бр. 8 (1906), стр. 171.

- Књижевност

562.

ЛОНЧАР-Трбојевић, Драга

У споменицу М. О. / Драга Лончар-Трбојевић // Год. 21, бр. 5 (1906), стр. 105.

- Књижевност

563.

ЛУЊЕВИЦА, Влада М.

Молио си / Влада М. Луњевица // Год. 21, бр. 9 (1906), стр. 209.

- Књижевност

564.

ЛУЊЕВИЦА, Влада М.

Неки воли / Влада М. Луњевица // Год. 21, бр. 9 (1906), стр. 209.

- Књижевност

565.

ЛУЊЕВИЦА, Влада М.

Непријатна новост / Влада М. Луњевица // Год. 21, бр. 5 (1906), стр. 99.

- Књижевност

566.

ЉУБАВ / Каја // Год. 21, бр. 5 (1906), стр. 102.

- Књижевност 
567.

ЉУБАВ и брак : Ellen Key / Ђ. В-ћ.// Год. 21, бр. 1 (1906), стр. 9-11.

- Женско питање

568.

ЉУБОМИР Р. Крсмановић // Год. 21, бр. 3 (1906), стр. 53-54.

- Биографије

569.

МАРИНКОВИЋ, Јулка Ф.

На гробу дра Паје Мандровића / Јулка Ф. Маринковића // Год. 21, бр. 6 (1906), стр. 122-123.

- Књижевност

570.

МАТЕРИНА љубав / с мађарског превео Благоје Бранчић // Год. 21, бр. 12 (1906), стр. 275-276.

- Књижевност

571.

МАТЕРИНСКА љубав / с руског Мира // Год. 21, бр. 6 (1906), стр. 133-134.

- Књижевност

572.

МАТЕРИНСКО удружење // Год. 21, бр. 2 (1906), стр. 25-28.

- Женско питање / Женски покрети

573.

МАТИ Хајнеова / В. // Год. 21, бр. 2 (1906), стр. 30-31.

- Биографије

574.

МАТИЈАШЕВИЋ, Димитрије Ј.

Кад би био / Димитрије Матијашевић Ј. // Год. 21, бр. 8 (1906), стр. 177.

- Књижевност

575.

МИЛОВАНОВ, Љуба

Мамина прва лекција / Љуба Милованов // Год. 21, бр. 1 (1906), стр. 13-14.

- Књижевност

576.

МИЛОЈКОВИЋ, Живан

Што ти око сузом сија / Жив. [Живан] Милојковић // Год. 21, бр. 12 (1906), стр. 268.

- Књижевност 
577.

МИРКОВИЋ, Боривоје Б.

In memoriam : моме покојноме добром другу Јовану В. Филиповићу / Боривоје Б.

Мирковић // Год. 21, бр. 8 (1906), стр. 178.

- Књижевност

578.

МИТРОВИЋ, Исаије

Из „Нових струна“ / Исаије Митровић // Год. 21, бр. 2 (1906), стр. 52-53.

- Књижевност

579.

МИТРОВИЋ, Исаије

Мојој сестри / Исаије Митровић // Год. 21, бр. 1 (1906), стр. 12.

- Књижевност

580.

МИТРОВИЋ, Исаије

На поласку из Бихаћа / Исаије Митровић // Год. 21, бр. 7 (1906), стр. 152.

- Књижевност

581.

МИТРОВИЋ, Исаије

Неста славуја / Исаије Митровић // Год. 21, бр. 3 (1906), стр. 55.

- Књижевност

582.

МИТРОВИЋ, Исаије

У албум : (гђици Анђелки Цветковићевој) / Исаије Митровић // Год. 21, бр. 1 (1906), стр. 3.

- Књижевност

583.

МИТРОВИЋ, Исаије

У албум : (Србима у Рајевцу) / Исаије Митровић // Год. 21, бр. 12 (1906), стр. 268.

- Књижевност

584.

МИТРОВИЋ, Исаије

Харемски цвет / Исаије Митровић // Год. 21, бр. 2 (1906), стр. 29.

- Књижевност

585.

МИТОРВИЋ, Исаије

Што нисам камен? / Исаије Миторвић // Год. 21, бр. 8 (1906), стр. 176. 
- Књижевност

586.

МОСТ уздисаја / Вукосава// Год. 21, бр. 9 (1906), стр. 199-200.

- Друштвено питање

587.

НА адресу српских Девојачких Кола // Год. 21, бр. 11 (1906), стр. 244-245.

- Женско питање / Женски покрети

588.

НА гробу чика Јовином / Вукосава // Год. 21, бр. 1 (1906), стр. 2.

- Књижевност

589.

НА почетку идуће школске године// Год. 21, бр. 8 (1906), стр. 169-170.

- Женско питање / Образовање

590.

НА рођен-дан / Ј. // Год. 21, бр. 7 (1906), стр. 160.

- Књижевност

591.

НАРОДЕ српски // Год. 21, бр. 5 (1906), стр. 105-106.

- Друштвено питање

592.

НАШИМ Српкињама // Год. 21, бр. 11 (1906), стр. 241-243.

- Женско питање / Женски покрети

593.

О срећи / по нем. М. Вујић // Год. 21, бр. 12 (1906), стр. 270-271.

- Књижевност

594.

ОДГОВОР на чланак „Раденичке школе“ / уредништво // Год. 21, бр. 6 (1906), стр. 123-124.

- Друштвено питање

595.

ОПРОШТАЈ Милеве Симићеве // Год. 21, бр. 7 (1906), стр. 152-154.

- Женско питање

596.

ОСТОЈИЋ, Јелена

У споменицу : сестри Ружи / Јел. [Јелена] Остојић // Год. 21, бр. 9 (1906), стр. 201. 
- Књижевност

597.

ПАУКОВИЋ, Ангелина

Пред врбицу / Ангелина Пауковић // Год. 21, бр. 4 (1906), стр. 80-81.

- Женско питање / Облачење

598.

ПЕШИЋ-Јованов, Лазар

Лети ми песмо / Лазар Пешић-Јованов // Год. 21, бр. 7 (1906), стр. 154.

- Књижевност

599.

ПОЗИВ српским учитељима и учитељицама у свим српским земљама / управа учитељског удружења // Год. 21, бр. 6 (1906), стр. 126-127.

- Друштвено питање

600.

ПОПОВИЋ, Јово Г.

Небрату / Јово Г. Поповић // Год. 21, бр. 8 (1906), стр. 176.

- Књижевност

601.

ПОПОВИЋ, Јово Г.

Ноћ / Јово Г. Поповић // Год. 21, бр. 5 (1906), стр. 105.

- Књижевност

602.

ПОПОВИЋ, Јово Г.

Први снијег / Јово Г. Поповић // Год. 21, бр. 5 (1906), стр. 106.

- Књижевност

603.

ПОПОВИЋ, Јулка Г.

Пошљедни пут / Јулка Г. Поповић // Год. 21, бр. 2 (1906), стр. 35-36.

- Књижевност

604.

ПРЕДАВАЮЕ гђе Савке Суботићке // Год. 21, бр. 8 (1906), стр. 173-176.

- Друштвено питање

605.

ПРОСВЕТА // Год. 21, бр. 1 (1906), стр. 20.

- Образовање

606. 
ПРОСВЕТА // Год. 21, бр. 2 (1906), стр. 43.

- Образовање

607.

ПРОСВЕТА // Год. 21, бр. 3 (1906), стр. 68-69.

- Образовање

608.

ПРОСВЕТА // Год. 21, бр. 4 (1906), стр. 92.

- Образовање

609.

ПРОСВЕТА // Год. 21, бр. 5 (1906), стр. 117.

- Образовање

610.

ПРОСВЕТА // Год. 21, бр. 6 (1906), стр. 141-142.

- Образовање

611.

ПРОСВЕТА // Год. 21, бр. 7 (1906), стр. 163-164.

- Образовање

612.

ПРОСВЕТА // Год. 21, бр. 8 (1906), стр. 188-189.

- Образовање

613.

ПРОСВЕТА // Год. 21, бр. 9 (1906), стр. 212-213.

- Образовање

614.

ПРОСВЕТА // Год. 21, бр. 10 (1906), стр. 238.

- Образовање

615.

ПРОСВЕТА // Год. 21, бр. 11 (1906), стр. 258.

- Женско питање / Образовање

616.

ПРОСВЕТА // Год. 21, бр. 12 (1906), стр. 280-281.

- Образовање

617.

РАД добротворних задруга Српкиња // Год. 21, бр. 1 (1906), стр. 17.

- Женско питање / Женски покрети 
618.

РАД добротворних задруга Српкиња // Год. 21, бр. 2 (1906), стр. 39.

- Женско питање / Женски покрети

619.

РАД добротворних задруга Српкиња // Год. 21, бр. 3 (1906), стр. 64-67.

- Женско питање / Женски покрети

620.

РАД добротворних задруга Српкиња // Год. 21, бр. 4 (1906), стр. 87-90.

- Женско питање / Женски покрети

621.

РАД добротворних задруга Српкиња // Год. 21, бр. 5 (1906), стр. 112-115.

- Женско питање / Женски покрети

622.

РАД добротворних задруга Српкиња // Год. 21, бр. 6 (1906), стр. 134-138.

- Женско питање / Женски покрети

623.

РАД добротворних задруга Српкиња // Год. 21, бр. 8 (1906), стр. 184-186.

- Женско питање / Женски покрети

624.

РАД добротворних задруга Српкиња // Год. 21, бр. 11 (1906), стр. 253-254.

- Женско питање / Женски покрети

625.

РАД добротворних задруга Српкиња // Год. 21, бр. 12 (1906), стр. 274-275.

- Женско питање / Женски покрети

626.

РАДАК, Јефта

Елегија 1905. години / Ј. Р-к. [Јефта Радак] // Год. 21, бр. 1 (1906), стр. 3.

- Књижевност

627.

РАДАК, Јефта

Поклич / J. Р-к. [Јефта Радак] // Год. 21, бр. 11 (1906), стр. 245.

- Књижевност

628.

РАДЕНИЧКЕ школе // Год. 21, бр. 5 (1906), стр. 97-99.

- Женско питање / Образовање 
629.

РАДУЛОВИЋ, Јела М.

А где је он? / Јела М. Радуловић // Год. 21, бр. 3 (1906), стр. 58.

- Књижевност

630.

РАДУЛОВИЋ, Јела М.

[Ако си уважен...] / Јела М. Радуловић // Год. 21, бр. 2 (1906), стр. 29.

- Књижевност

631.

РАДУЛОВИЋ, Јела М.

Кад се спусти ноћни вео / Јела Миленка Радуловића // Год. 21, бр. 9 (1906), стр. 209.

- Књижевност

632.

РАЗНО // Год. 21, бр. 1 (1906), стр. 21.

- Вести

633.

РАЗНО // Год. 21, бр. 2 (1906), стр. 43.

- Вести

634.

РАЗНО // Год. 21, бр. 3 (1906), стр. 69.

- Вести

635.

РАЗНО // Год. 21, бр. 5 (1906), стр. 117.

- Вести

636.

РАЗНО // Год. 21, бр. 7 (1906), стр. 164-165.

- Вести

637.

РАЗНО // Год. 21, бр. 9 (1906), стр. 213.

- Вести

638.

РАЗНО // Год. 21, бр. 11 (1906), стр. 259-260.

- Вести

639.

РАЗНО // Год. 21, бр. 11 (1906), стр. 259-260. 
- Вести

640.

РАКОШИ, Виктор

Мужевљева прича / Виктор Ракоши ; превела М. М. рођ. С. [Мила Малеташка] // Год. 21, бр. 2 (1906), стр. 37-38.

- Књижевност

641.

РАШИЋ, Војислав

Вечно / Биослав // Год. 21, бр. 8 (1906), стр. 171.

- Књижевност

642.

РАШИЋ, Војислав

Што су ти људи / Биослав // Год. 21, бр. 7 (1906), стр. 151.

- Књижевност

643.

СЕНИ : из циклуса Песме у прози / Мира // Год. 21, бр. 3 (1906), стр. 61-64.

- Књижевност

644.

СИМИЋ, Милева

Наши купци и трговци / Милева Симићева // Год. 21, бр. 10 (1906), стр. 219-221.

- Друштвено питање

645.

СИМИЋ, Милева

Свој своме / Милева Симићева // Год. 21, бр. 9 (1906), стр. 195-198.

- Женско питање / Родитељство

646.

СРПСКА мајка : борба на Великој Очи у Ст. Србији 1905. г. // Год. 21, бр. 1 (1906), стр. 16.

- Друштвено питање

647.

СРПСКА народна ношња / Тетка Божана // Год. 21, бр. 11 (1906), стр. 245-246.

- Женско питање / Ношња

648.

СРПСКА свадба весела је / Н. 3. // Год. 21, бр. 6 (1906), стр. 126.

- Књижевност

649. 
СТОЈШИЋ, Димитрије

Болесник / Дим. [Димитрије] Стојшић // Год. 21, бр. 9 (1906), стр. 199.

- Књижевност

650.

СТОЛПОВИЋ, Драгомир Е.

Не дајмо своје / Драг. [Драгомир] Е. Столповић // Год. 21, бр. 1 (1906), стр. 11-12.

- Женско питање / Ношња

651.

СТОЛПОВИЋ, Драгомир Е.

Не примајмо туђе зло / Драг. [Драгомир] Е. Столповић // Год. 21, бр. 8 (1906), стр. 176-177.

- Друштвено питање

652.

СТРАХ од свекрве / Мира // Год. 21, бр. 9 (1906), стр. 201-207.

- Књижевност

653.

СУБОТИЋ, Савка

Пролеће у Цариграду / Савка Суботић // Год. 21, бр. 7 (1906), стр. 154-158.

- Књижевност

654.

ТИ велиш / Ј. Париводић // Год. 21, бр. 11 (1906), стр. 248.

- Књижевност

655.

ТРИФУНОВИЋ, Милан М.

Општинска Вага : Јови Поповићу / Милан М. Трифуновић // Год. 21, бр. 11 (1906), стр. 248-249.

- Књижевност

656.

ЋИРИЋ, Радивој П.

Моја зима / Рад. [Радивој] П. Ћирић // Год. 21, бр. 3 (1906), стр. 54.

- Књижевност

657.

ЋИРИЋ, Радивој П.

Највећа жеља / Рад. [Радивој] П. Ћирић // Год. 21, бр. 4 (1906), стр. 80.

- Књижевност

658.

ЋИРИЋ, Радивој П. 
Наша кућа / Рад. [Радивој] П. Ћирић // Год. 21, бр. 2 (1906), стр. 32.

- Књижевност

659.

ЋИРИЋ, Радивој П.

Небесни дар / Рад. [Радивој] П. Ћирић // Год. 21, бр. 12 (1906), стр. 271.

- Књижевност

660.

ЋИРИЋ, Радивој П.

Ти / Рад. [Радивој] П. Ћирић // Год. 21, бр. 9 (1906), стр. 199.

- Књижевност

661.

У ДОБА ноћног мира / Миле // Год. 21, бр. 11 (1906), стр. 243.

- Књижевност

662.

УДАљЕНОЈ / Војислав // Год. 21, бр. 2 (1906), стр. 28.

- Књижевност

663.

УДАљЕНОМ / Каја // Год. 21, бр. 4 (1906), стр. 82.

- Књижевност

664.

УМЕТНОСТ // Год. 21, бр. 7 (1906), стр. 165.

- Вести

665.

ЦЕНИЋ, Боривоје Л.

На овоме свету / Бор. [Боривоје] Л. Ценић // Год. 21, бр. 8 (1906), стр. 173.

- Књижевност

666.

ЦЕНИЋ, Боривоје Л.

У баштици / Бор. [Боривоје] Л. Ценић // Год. 21, бр. 2 (1906), стр. 31.

- Књижевност

667.

ЦУЦУ / превела Вукосава // Год. 21, бр. 11 (1906), стр. 250-253.

- Књижевност

668.

ЧИТУљА // Год. 21, бр. 1 (1906), стр. 19-20.

- Вести / Некролог 
669.

ЧИТУљА // Год. 21, бр. 2 (1906), стр. 40-42.

- Вести / Некролог

670.

ЧИТУљА // Год. 21, бр. 3 (1906), стр. 68.

- Вести / Некролог

671.

ЧИТУљА // Год. 21, бр. 4 (1906), стр. 92.

- Вести / Некролог

672.

ЧИТУљА // Год. 21, бр. 5 (1906), стр. 116-117.

- Вести / Некролог

673.

ЧИТУљА // Год. 21, бр. 6 (1906), стр. 140-141.

- Вести / Некролог

674.

ЧИТУљА // Год. 21, бр. 7 (1906), стр. 162-163.

- Вести / Некролог

675.

ЧИТУљА // Год. 21, бр. 8 (1906), стр. 188.

- Вести / Некролог

676.

ЧИТУљА // Год. 21, бр. 9 (1906), стр. 211-212.

- Вести / Некролог

677.

ЧИТУљА // Год. 21, бр. 10 (1906), стр. 237-238.

- Вести / Некролог

678.

ЧИТУљА // Год. 21, бр. 11 (1906), стр. 255-257.

- Вести / Некролог

679.

ЧИТУљА // Год. 21, бр. 12 (1906), стр. 279-280.

- Вести / Некролог

680. 
ШАНТИЋ, Јаков

Покрај мора / Јаков Шантић // Год. 21, бр. 2 (1906), стр. 32.

- Књижевност

681.

ШПАДИЈЕР, Ђуро

Госођици / Ђ. [Ђуро] Шпадијер // Год. 21, бр. 4 (1906), стр. 86.

- Књижевност 


\section{7.}

682.

АВРАМОВИЋ, Милан

Да ти певам! / Милан Аврамовић // Год. 22, бр. 7-8 (1907), стр. 168.

- Књижевност

683.

АВРАМОВИЋ, Милан

На путу дужности / Милан Аврамовић // Год. 22, бр. 7-8 (1907), стр. 179-180.

- Књижевност

684.

АВРАМОВИЋ, Милан

На заходу у селу! / Милан Аврамовић // Год. 22, бр. 9 (1907), стр. 203-204.

- Књижевност

685.

АВРАМОВИЋ, Милан

Што ме питаш / Милан Ј. Аврамовић // Год. 22, бр. 10 (1907), стр. 224.

- Књижевност

686.

АВРАМОВИЋ, Милан

Љубићу те до издаха / Милан Ј. Аврамовић // Год. 22, бр. 11 (1907), стр. 248.

- Књижевност

687.

БЕЛОВИЋ, Јелица

Наши народни везови на изложби у Ишлу / Јелица Беловићева // Год. 22, бр. 7-8 (1907), стр. 160-161.

- Женско питање / Ручни рад

688.

БЕЛЕШКЕ // Год. 22, бр. 10 (1907), стр. 232-233.

- Женско питање / Вести

689.

БОГОРОДИЦА и анђели / превео Ž - Агсо // Год. 22, бр. 1 (1907), стр. 14-15.

- Хришћанство

690.

БОЖАНСТВЕНА поезија / Хришћанка // Год. 22, бр. 9 (1907), стр. 196.

- Књижевност 
691.

БУљА, Даринка

Дете среће / Даринка Буља // Год. 22, бр. 2 (1907), стр. 35-36.

- Књижевност

692.

БУљА, Даринка

Са села / Даринка Буља // Год. 22, бр. 9 (1907), стр. 205-206.

- Књижевност

693.

ВАРАЋАНИН, Аркадије

Учитељице у служби народног здравља / Аркадије Варађанин // Год. 22, бр. 3 (1907), стр. 49-51.

- Образовање / Здравље

694.

ВАШЉИВА деца // Год. 22, бр. 1 (1907), стр. 9-10.

- Здравље

695.

ВЕТРИЋ пири / А // Год. 22, бр. 3 (1907), стр. 57.

- Књижевност

696.

ВИДИМ да морам / Атлета // Год. 22, бр. 7-8 (1907), стр. 154.

- Књижевност

697.

ВУЈИЋ, М.

Ускрс старог звонара / М. Вујић // Год. 22, бр. 5 (1907), стр. 110-112.

- Књижевност

698.

ГАВРИЛОВИЋ, Миливој М.

Молитва мојој Зори / Миливој М. Гавриловић // Год. 22, бр. 3 (1907), стр. 52.

- Књижевност

699.

ГАВРИЛОВИЋ, Миливој М.

Збогом / М. [Миливој] М. Гавриловић // Год. 22, бр. 6 (1907), стр. 131.

- Књижевност

700.

ГАВРИЛОВИЋ, Милутин 
Талијанска краљица Јелена / Милутин Гавриловић // Год. 22, бр. 7-8 (1907), стр. 173175.

- Биографије

701.

ГЛАСНИК // Год. 22, бр. 1 (1907), стр. 18-20.

- Вести

702.

ГЛАСНИК // Год. 22, бр. 2 (1907), стр. 39-43.

- Вести

703.

- Вести

ГЛАСНИК // Год. 22, бр. 3 (1907), стр. 66-67.

704.

ГЛАСНИК // Год. 22, бр. 4 (1907), стр. 90-91.

- Вести

705.

ГЛАСНИК // Год. 22, бр. 5 (1907), стр. 115-116.

- Вести

706.

ГЛАСНИК // Год. 22, бр. 6 (1907), стр. 138-139.

- Женско питање / Вести

707.

ГЛАСНИК // Год. 22, бр. 7-8 (1907), стр. 185-187.

- Женско питање / Вести

708.

ГЛАСНИК // Год. 22, бр. 9 (1907), стр. 211-212.

- Женско питање / Вести

709.

ГЛАСНИК // Год. 22, бр. 11 (1907), стр. 259-260.

- Женско питање / Вести

710.

ГЛАСНИК // Год. 22, бр. 12 (1907), стр. 279-281.

- Женско питање / Вести

711.

ГРГУРОВА, Милка 
Мара буњевка / Милка Гргурова // Год. 22, бр. 9 (1907), стр. 206-210.

- Књижевност

712.

ГРГУРОВА, Милка

Мара буњевка / Милка Гргурова // Год. 22, бр. 10 (1907), стр. 229-230.

- Књижевност

713.

ДАВИД, Илић

На смрт шестогодишње Љепосаве Мандолфо / Давид Илић // Год. 22, бр. 3 (1907), стр. 52.

- Књижевност

714.

ДЕСПРЕО, Боало

Утеха : (писмо Бросету поводом смрти његове матере) / Боало Деспрео ; превела с француског Данка Ј. Митрановићева // Год. 22, бр. 3 (1907), стр. 61.

- Преписка

715.

ДЕСЕТОГОДИШЫИЦА „Привредника“ // Год. 22, бр. 10 (1907), стр. 239.

- Вести

716.

ДЕСЕТОГОДИШЊА прослава Добротворне Задруге Српкиња Сомборкиња // Год. 22, бр. 1 (1907), стр. 4-9.

- Женско питање / Женски покрети

717.

ДЕЧЈИ дан // Год. 22, бр. 4 (1907), стр. 73-74.

- Женски покрети

718.

ДИКЛИЋ, Славко С.

Мраморни кип / Славко С. Диклић // Год. 22, бр. 7-8 (1907), стр. 151.

- Књижевност

719.

ДИКЛИЋ, Славко С.

Крај реке / Славко С. Диклић // Год. 22, бр. 7-8 (1907), стр. 154.

- Књижевност

720.

ДИКЛИЋ, Славко С.

Сирочад / Славко С. Диклић // Год. 22, бр. 7-8 (1907), стр. 167. 
- Књижевност

721.

ДОПИСИ // Год. 22, бр. 2 (1907), стр. 31-32.

- Женско питање / Вести

722.

ДОПИСИ / А. И. // Год. 22, бр. 3 (1907), стр. 55-57.

- Женско питање / Вести

723.

ДОПИСИ // Год. 22, бр. 4 (1907), стр. 79-81.

- Женско питање / Вести

724.

ДОПИСИ // Год. 22, бр. 5 (1907), стр. 105.

- Женско питање / Вести

725.

ДОПИСИ / Драган // Год. 22, бр. 6 (1907), стр. 129-131.

- Женско питање / Вести

726.

ДОПИСИ / тетка Божана // Год. 22, бр. 7-8 (1907), стр. 168-169.

- Женско питање / Вести

727.

ДОПИСИ / Ј. Н. Д. // Год. 22, бр. 9 (1907), стр. 202.

- Женско питање / Вести

728.

ДОПИСИ / М. К. М. // Год. 22, бр. 10 (1907), стр. 226-228.

- Женско питање / Вести

729.

ЗДРАВЉЕ // Год. 22, бр. 1 (1907), стр. 21.

- Здравље / Хигијена

730.

ЖЕНА у физичко-психолошком погледу / с руског Саватије М. Грбић // Год. 22, бр. 7-8 (1907), стр. 148-150.

- Женско питање

731.

ЖИВКОВИЋ, Тодор

Књиге и наше женске / Тодор Живковић // Год. 22, бр. 7-8 (1907), стр. 145-147. 
- Женско питање / Образовање

732.

ЖИВОЈНОВИЋ, Јован

Сећање / Јован Живојновић // Год. 22, бр. 2 (1907), стр. 27.

- Књижевност

733.

ЖИВОЈНОВИЋ, Јован

Сокоска песма / Јован Живојновић // Год. 22, бр. 12 (1907), стр. 266.

- Књижевност

734.

ЖРТВЕ прилике / по мађ). М. Вујић // Год. 22, бр. 3 (1907), стр. 54-55.

- Женско питање

735.

ЗА домаћице // Год. 22, бр. 4 (1907), стр. 92.

- Женско питање / Савети

736.

ЗА домаћице // Год. 22, бр. 5 (1907), стр. 117.

- Женско питање / Савети

737.

ЗА домаћице // Год. 22, бр. 6 (1907), стр. 142-143.

- Женско питање / Савети

738.

ЗА домаћице // Год. 22, бр. 7-8 (1907), стр. 190.

- Женско питање / Савети

739.

ЗА домаћице // Год. 22, бр. 9 (1907), стр. 215.

- Женско питање / Савети

740.

ЗА домаћице // Год. 22, бр. 10 (1907), стр. 235.

- Женско питање / Савети

741.

ЗА домаћице // Год. 22, бр. 11 (1907), стр. 263.

- Женско питање / Савети

742.

ЗЕБИЋ, Стеван 
Песма / Стеван Зебић-Горски // Год. 22, бр. 9 (1907), стр. 197.

- Књижевност

743.

ЗБОГОМ / Вук // Год. 22, бр. 10 (1907), стр. 223.

- Књижевност

744.

ИВАНИЋ, Иван

Српске женске рукотворине у Лондону / Иван Иванић // Год. 22, бр. 6 (1907), стр. 126-127.

- Женско питање - Ручни рад

745.

ИВАНИЋ, Иван

Српске женске рукотворине на балканској изложби / Иван Иванић // Год. 22, бр. 7-8 (1907), стр. 158-159.

- Женско питање / Ручни рад

746.

ИГРА као васпитно средство / М.С. // Год. 22, бр. 9 (1907), стр. 200-202.

- Васпитање / Савети

747.

ИЗ живота једног министра / превео Душан // Год. 22, бр. 7-8 (1907), стр. 181-184.

- Књижевност

748.

ИЗ пјесама по растанку / Атлета // Год. 22, бр. 7-8 (1907), стр. 160.

- Књижевност

749.

ИЗ светлих дана / Ђ. Л. Маринко // Год. 22, бр. 6 (1907), стр. 127.

- Књижевност

750.

ИЗ уздаха / Атлета // Год. 22, бр. 3 (1907), стр. 65-66.

- Књижевност

751.

ИНДИЈСКА жена / превела Савка // Год. 22, бр. 10 (1907), стр. 222-223.

- Женско питање

752.

ЈАБЛАНОВИЋ, Анто

Ноћ је тиха / Анто Јаблановић // Год. 22, бр. 2 (1907), стр. 33. 
- Књижевност

753.

ЈЕСЕН : по Петефију / Маринко // Год. 22, бр. 1 (1907), стр. 9.

- Књижевност

754.

JЕВТОВИЋ, Димитрије

Ждрали / Димитрије Јевтовић-Полимац // Год. 22, бр. 7-8 (1907), стр. 122.

- Књижевност

755.

ЈЕДНА херцеговачка списатељка // Год. 22, бр. 9 (1907), стр. 198-200.

- Биографије

756.

ЈЕСЕНСКИ дан / Атлета // Год. 22, бр. 10 (1907), стр. 221.

- Књижевност

757.

КАРАБЕГОВИЋ, Авдо

Шта си стала, шта ме гледаш? / Авдо Карабеговић // Год. 22, бр. 4 (1907), стр. 76.

- Књижевност

758.

КАРАБЕГОВИЋ, Авдо

Ходи драга / Авдо Карабеговић // Год. 22, бр. 4 (1907), стр. 90.

- Књижевност

759.

КЊИЖЕВНОСТ// Год. 22, бр. 1 (1907), стр. 22.

- Вести / Књижевност

760.

КЊИЖЕВНОСТ// Год. 22, бр.2 (1907), стр. 45-46.

- Вести / Књижевност

761.

КЊИЖЕВНОСТ // Год. 22, бр. 3 (1907), стр. 68-69.

- Вести / Књижевност

762.

КЊИЖЕВНОСТ // Год. 22, бр. 4 (1907), стр. 93.

- Вести / Књижевност

763. 
КњИЖЕВНОСТ // Год. 22, бр. 5 (1907), стр. 118-119.

- Вести / Књижевност

764.

КЬИЖЕВНОСТ // Год. 22, бр. 6 (1907), стр. 143-144.

- Вести / Књижевност

765.

КЊИЖЕВНОСТ // Год. 22, бр. 7-8 (1907), стр. 190-191.

- Вести / Књижевност

766.

КњИЖЕВНОСТ // Год. 22, бр. 9 (1907), стр. 215.

- Вести / Књижевност

767.

КНИЖЕВНОСТ // Год. 22, бр. 10 (1907), стр. 235-239.

- Вести / Књижевност

768.

КЊИЖЕВНОСТ // Год. 22, бр. 11 (1907), стр. 264.

- Вести / Књижевност

769.

КњИЖЕВНОСТ // Год. 22, бр. 12 (1907), стр. 283-284.

- Вести / Књижевност

770.

КОЈИЋ, Ђорђе С.

Психологија женскиња / Ђорђе С. Којић // Год. 22, бр. 4 (1907), стр. 76-78.

- Женско питање / Психологија

771.

КОСТИЋ, Олга

Мати / Олга Костић // Год. 22, бр. 7-8 (1907), стр. 152-154.

- Женско питање /Родитељство

772.

КРАЉИЦА Јелена као уметница // Год. 22, бр. 6 (1907), стр. 128-129.

- Биографије

773.

КРСТИЋ, Васа

Ал’ је лепа ... / Др. Казбулбуц // Год. 22, бр. 2 (1907), стр. 27.

- Књижевност 
774.

КРСТИЋ, Васа

Вели Негриновој / Др. Казбулбуц // Год. 22, бр. 11 (1907), стр. 243.

- Књижевност

775.

КРСТИЋ, Васа

Сусрело се пролеће и зима / Др. Казбулбуц // Год. 22, бр. 12 (1907), стр. 272.

- Књижевност

776.

ЛАЗАРЕВИЋ, Јелена

Међународни женски савез и Српкиње / Јелена Лазаревићева // Год. 22, бр. 6 (1907), стр. 121-125.

- Женско питање / Женски покрети

777.

ЛАЗИЋ, Ђорђе

Деца смо били / Ђорђе Лазић-Маринко // Год. 22, бр. 9 (1907), стр. 198.

- Књижевност

778.

ЛАЗИЋ, Ђорђе

На те мислим / Ђорђе Лазић // Год. 22, бр. 10 (1907), стр. 226.

- Књижевност

779.

ЛИЧАНИН, Мара

Душа и славуј / Мара Личанинова // Год. 22, бр. 7-8 (1907), стр. 152.

- Књижевност

780.

ЛОНЧАР ТРБОЈЕВИЋ, Драга

Никада нисам / Драга Лончар Трбојевић // Год. 22, бр. 1 (1907), стр. 11.

- Књижевност

781.

ЛОНЧАР ТРБОЈЕВИЋ, Драга

Крсноме имену! / Драга Лончар Трбојевић // Год. 22, бр. 1 (1907), стр. 18.

- Књижевност

782.

ЛОНЧАР ТРБОЈЕВИЋ, Драга

Мојим гробовима! / Драг. Лончар-Трбојевић // Год. 22, бр. 6 (1907), стр. 132.

- Књижевност 
783.

ЛОНЧАР ТРБОЈЕВИЋ, Драга

Пролећу! / Драга Лончар-Трбојевић // Год. 22, бр. 11 (1907), стр. 249.

- Књижевност

784.

ЛОНЧАР ТРБОЈЕВИЋ, Драга

Напех струне / Драга Лончар-Трбојевић // Год. 22, бр. 11 (1907), стр. 259.

- Књижевност

785.

ЛУњЕВИЦА, Влада М.

Ново лето / Влада М. Луњевица // Год. 22, бр. 1 (1907), стр. 3.

- Књижевност

786.

ЛУњЕВИЦА, Влада М.

Жале се на зиму / Влада М. Луњевица // Год. 22, бр. 4 (1907), стр. 76.

- Књижевност

787.

ЛУњЕВИЦА, Влада М.

Каз’о би ти / Влада М. Луњевица // Год. 22, бр. 5 (1907), стр. 102.

- Књижевност

788.

ЛУњЕВИЦА, Влада М.

Кад сам јоште мали био / Влада М. Луњевица // Год. 22, бр. 6 (1907), стр. 125.

- Књижевност

789.

ЛУњЕВИЦА, Влада М.

Хумористичке песме / Влада М. Луњевица // Год. 22, бр. 7-8 (1907), стр. 147. Садржи песме: Дијалог о женама ; Има среће за свакога ; То би слатко било ; Срећна ружица.

- Књижевност

790.

ЛУЮЕВИЦА, Влада М.

Једини гост / Влада М. Луњевица // Год. 22, бр. 9 (1907), стр. 200.

- Књижевност

791.

ЛУњЕВИЦА, Влада

У осами / Влада : Луњевица // Год. 22, бр. 10 (1907), стр. 219.

- Књижевност 
792.

ЛУЊЕВИЦА, Влада М.

Кад смрт хладна закуца / Влада М. Луњевица // Год. 22, бр. 10 (1907), стр. 221.

- Књижевност

793.

МАЈСКА ноћ / Атлета // Год. 22, бр. 6 (1907), стр. 125.

- Књижевност

794.

МАНОЈЛОВИЋ, Светозар

Најмилије цвеће / из Шароперки Светозара Манојловића // Год. 22, бр. 5 (1907), стр. 103.

- Књижевност

795.

МАРИНА песма / Цвет. // Год. 22, бр. 6 (1907), стр. 136.

- Књижевност

796.

МИЛОВАНОВ, Љуба

На селу / Љуба Милованов // Год. 22, бр. 6 (1907), стр. 136-137.

- Књижевност

797.

МИТРОВИЋ, Исаије

Мамино злато / Исаије Митровић // Год. 22, бр. 7-8 (1907), стр. 160.

- Књижевност

798.

МИТРОВИЋ, Исаије

Из „Посавкиња“ / Исаије Митровић // Год. 22, бр. 7-8 (1907), стр. 162.

- Књижевност

799.

МИЦИЈЕВИЋ, Адам

Кога да изаберем за мужа / Адам Мицијевић ; превела Јованка Л. Лонткијевићева // Год. 22, бр. 1 (1907), стр. 16-18.

- Књижевност

800.

МОДА / С. // Год. 22, бр. 10 (1907), стр. 217-219.

- Женско питање / Мода

801.

МОЈА жеља / J // Год. 22, бр. 4 (1907), стр. 74. 
- Књижевност

802.

МУДРА зова / с енглеског прев. Милена Грбић // Год. 22, бр. 5 (1907), стр. 112-113.

- Књижевност

803.

НА твој прекор / Ј. // Год. 22, бр. 2 (1907), стр. 31.

- Књижевност

804.

НА пољани / Вук // Год. 22, бр. 7-8 (1907), стр. 151.

- Књижевност

805.

НА сестрином гробу // Год. 22, бр. 10 (1907), стр. 231.

- Књижевност

806.

НАДА / Вук // Год. 22, бр. 12 (1907), стр. 271.

- Књижевност

807.

НАДОПУЊЕНО / с немачког Мира // Год. 22, бр. 7-8 (1907), стр. 175-179.

- Књижевност

808.

НАРОДНИ златовез у Срба // Год. 22, бр. 7-8 (1907), стр. 155-156.

- Женско питање / Ручни рад

809.

НОВИ живот / Родољуб // Год. 22, бр. 5 (1907), стр. 100.

- Књижевност

810.

ЊЕГОВА љубав / Атлета // Год. 22, бр. 11 (1907), стр. 255-256.

- Књижевност

811.

ЊОЈ / Вук // Год. 22, бр. 6 (1907), стр. 128.

- Књижевност

812.

О нези и одржавању лепоте // Год. 22, бр. 12 (1907), стр. $288 .$.

- Женско питање 
813.

ОРГАНИЗОВАЮЕ сеоских женских радионица // Год. 22, бр. 9 (1907), стр. 197-198.

- Женско питање / Ручни рад

814.

ОРГАНИЗОВАЮЕ сеоских женских радионица // Год. 22, бр. 10 (1907), стр. 224-225

- Женско питање / Ручни рад

815.

ОСВЈЕТНА кошуља : догађај из црногорског живота / са нјемачког превела Милица Велебит // Год. 22, бр. 2 (1907), стр. 33-34.

- Култура / Етнографија

816.

ПЕСНИКОВ сан / превео Хуго Фишеровић // Год. 22, бр. 5 (1907), стр. 104.

- Књижевност

817.

ПЕШИЋ, Лазар

У мирисно цвеће / Лазар Пешић Јованов // Год. 22, бр. 6 (1907), стр. 129.

- Књижевност

818.

ПЕШИЋ, Лазар

Српкиња си! / Лазар Пешић Јованов // Год. 22, бр. 7-8 (1907), стр. 154.

- Књижевност

819.

ПИТАО сам / Маринко // Год. 22, бр. 4 (1907), стр. 79.

- Књижевност

820.

ПОПОВИЋ, Драгутин Т.

У сутон / Драгутин Т. Поповић // Год. 22, бр. 9 (1907), стр. 204-205.

- Књижевност

821.

ПОПОВИЋ, Драгутин Т.

Жреци талије / Драгутин Т. Поповић // Год. 22, бр. 11 (1907), стр. 256.

- Књижевност

822.

ПОПОВИЋ, Драгутин Т.

Изгубљен рај / Драгутин Т. Поповић // Год. 22, бр. 12 (1907), стр. 274-275.

- Књижевност 
823.

ПОПОВИЋ, Јово Г.

Куку! / Јово Г. Поповић // Год. 22, бр. 10 (1907), стр. 219.

- Књижевност

824.

ПОПОВИЋ, Јулка Г.

Дуња / Јулка Г. Поповић // Год. 22, бр. 1 (1907), стр. 11-14.

- Књижевност

825.

ПОПОВИЋ, Јулка Г.

Пелка : другарици Даници Самарџији / Јулка Г. Поповић // Год. 22, бр. 3 (1907), стр. 58-59.

- Књижевност

826.

ПОСЛЕ жура / В. К. Љубисав // Год. 22, бр. 7-8 (1907), стр. 180-181.

- Књижевност

827.

ПРВА изложба женског ручног рада у Чуругу / М. К. М. // Год. 22, бр. 7-8 (1907), стр. 151-152.

- Женско питање / Ручни рад

828.

ПРВИ пут међу дјечицом / Ј. П. - Дуња // Год. 22, бр. 10 (1907), стр. 230-231.

- Књижевност

829.

ПРЕ развода / прерадила М. К. М // Год. 22, бр. 4 (1907), стр. 86-89.

- Књижевност

830.

ПРОСВЕТА // Год. 22, бр. 1 (1907), стр. 21.

- Образовање / Педагогија

831.

ПРОСВЕТА // Год. 22, бр. 3 (1907), стр. 67-68.

- Образовање / Педагогија

832.

ПРОСВЕТА // Год. 22, бр. 4 (1907), стр. 92.

- Образовање / Педагогија

833. 
ПРОСВЕТА // Год. 22, бр. 5 (1907), стр. 92.

- Образовање / Педагогија

834.

ПРОСВЕТА // Год. 22, бр. 6 (1907), стр. 142.

- Образовање / Педагогија

835.

ПРОСВЕТА // Год. 22, бр. 7-8 (1907), стр. 189-190.

- Образовање / Педагогија

836.

ПРОСВЕТА // Год. 22, бр. 9 (1907), стр. 215.

- Образовање / Педагогија

837.

ПРОСВЕТА // Год. 22, бр. 10 (1907), стр. 235.

- Образовање / Педагогија

838.

ПРОСВЕТА // Год. 22, бр. 11 (1907), стр. 263.

- Образовање / Педагогија

839.

ПРОСВЕТА // Год. 22, бр. 12 (1907), стр. 282-283.

- Образовање / Педагогија

840.

ПСИХОЛОГИЈА женскиња // Год. 22, бр. 3 (1907), стр. 53-54.

- Женско питање / Психологија

841.

РАД добротворних задруга Српкиња // Год. 22, бр. 2 (1907), стр. 37-39.

- Женско питање / Женски покрети

842.

РАД добротворних задруга Српкиња // Год. 22, бр. 3 (1907), стр. 61-65.

- Женско питање / Женски покрети

843.

РАД добротворних задруга Српкиња // Год. 22, бр. 4 (1907), стр. 79-81.

- Женско питање / Женски покрети

844.

РАД добротворних задруга Српкиња // Год. 22, бр. 5 (1907), стр. 105-110.

- Женско питање / Женски покрети 
845.

РАД добротворних задруга Српкиња // Год. 22, бр. 6 (1907), стр. 132-136

- Женско питање / Женски покрети

846.

РАД добротворних задруга Српкиња // Год. 22, бр. 7-8 (1907), стр. 169-171.

- Женско питање / Женски покрети

847.

РАД добротворних задруга Српкиња // Год. 22, бр. 9 (1907), стр. 202-203.

- Женско питање / Женски покрети

848.

РАД добротворних задруга Српкиња // Год. 22, бр. 10 (1907), стр. 228.

- Женско питање / Женски покрети

849.

РАД добротворних задруга Српкиња // Год. 22, бр. 11 (1907), стр. 253-255.

- Женско питање / Женски покрети

850.

РАД добротворних задруга Српкиња // Год. 22, бр. 12 (1907), стр. 271-272.

- Женско питање / Женски покрети

851.

РАД и наука // Год. 22, бр. 1 (1907), стр. 1-3.

- Женско питање / Ручни рад

852.

РАДОСАВљЕВИЋ, Паја Р.

Проучавање ђака / Паја Р. Радосављевић // Год. 22, бр. 11 (1907), стр. 249-253.

- Педагогија

853.

РАДОСАВљЕВИЋ, Паја Р.

Проучавање ђака / Паја Р. Радосављевић // Год. 22, бр. 12 (1907), стр. 266-270.

- Педагогија

854.

РАДОСНА вест // Год. 22, бр. 2 (1907), стр. 25-26.

- Женско питање / Образовање

855.

РАЗНО // Год. 22, бр. 1 (1907), стр. 21.

- Вести 
856.

РАЗНО // Год. 22, бр. 2 (1907), стр. 45.

- Вести

857.

РАЗНО // Год. 22, бр. 3 (1907), стр. 68.

- Вести

858.

РАЗНО // Год. 22, бр. 4 (1907), стр. 92-93.

- Вести

859.

РАЗНО // Год. 22, бр. 5 (1907), стр. 117-118.

- Вести

860.

РАЗНО // Год. 22, бр. 6 (1907), стр. 143.

- Вести

861.

РАЗНО // Год. 22, бр. 10 (1907), стр. 235.

- Вести

862.

РАЗНО // Год. 22, бр. 11 (1907), стр. 263-264.

- Вести

863.

РАКИЋ, Михаило

Положај женскиње у старом завету / од поп Михаила Ракића // Год. 22, бр. 11 (1907), стр. 245-248.

- Женско питање

864.

РАШИЋ, Војислав

Јади, јади / Биослав // Год. 22, бр. 2 (1907), стр. 27.

- Књижевност

865.

РАШИЋ, Војислав

Јек / Биослав // Год. 22, бр. 4 (1907), стр. 76.

- Књижевност

866. 
РАШИЋ, Војислав

У споменицу / Биосав // Год. 22, бр. 7-8 (1907), стр. 167.

- Књижевност

867.

РОЂЕН-дан / Атлета // Год. 22, бр. 7-8 (1907), стр. 155.

- Књижевност

868.

РУСКЕ жене // Год. 22, бр. 4 (1907), стр. 74-75.

- Женски покрети

869.

РУСКЕ жене / Милица // Год. 22, бр. 5 (1907), стр. 100-102.

- Женски покрети

870.

СВИЛАРСТВО у 1906. год. / Ј. Ж. // Год. 22, бр. 5 (1907), стр. 97-100.

- Култура

871.

СРЕДАНОВИЋ, Ф.

За емансипацију Српкиња / Ф. Средановић // Год. 22, бр. 10 (1907), стр. 220-221.

- Женско питање / Образовање

872.

СРПКИњО / Марија // Год. 22, бр. 3 (1907), стр. 51.

- Књижевност

873.

СРПСКО девојачко коло у Сомбору // Год. 22, бр. 11 (1907), стр. 241-243.

- Женско питање /Женски покрети

874.

СТОЈАЧИЋ, К.

Црна ноћ / К. Стојачић // Год. 22, бр. 12 (1907), стр. 272-274.

- Књижевност

875.

СТОЈКОВИЋ, Ди. П.

Тиче / Ди. П. Стојковић // Год. 22, бр. 7-8 (1907), стр. 156.

- Књижевност

876.

СТОЈШИЋ, Димитрије П.

Пут / Дим. [Димитрије] П. Стојшић // Год. 22, бр. 3 (1907), стр. 54-55. 
- Књижевност

877.

СТОЈШИЋ, Димитрије П.

Признање / Димитрије П. Стојшић // Год. 22, бр. 7-8 (1907), стр. 148.

- Књижевност

878.

СТОЈШИЋ, Димитрије П.

Синови ноћи / Димитрије П. Стојшић // Год. 22, бр. 7-8 (1907), стр. 169.

- Књижевност

879.

СТОЈШИЋ, Димитрије П.

Ноћ је / Димитрије П. Стојшић // Год. 22, бр. 10 (1907), стр. 226.

- Књижевност

880.

СТОЈШИЋ, Димитрије П.

Вече на Дунаву / Димитрије П. Стојшић // Год. 22, бр. 11 (1907), стр. 245.

- Књижевност

881.

СТОЈШИЋ, Димитрије П.

Мојој сестри Александри / Димитрије П. Стојшић // Год. 22, бр. 12 (1907), стр. 270.

- Књижевност

882.

СТОЛПОВИЋ, Драгомир Е.

Како се шири мода код сеоскога женскиња / Драгомир Е. Столповић // Год. 22, бр. 12 (1907), стр. 265.

- Женско питање

883.

СТРАНИ листови о Савки Суботићки // Год. 22, бр. 9 (1907), стр. 195.

- Биографије

884.

СТУД / Јова // Год. 22, бр. 1 (1907), стр. 3.

- Књижевност

885.

СУБОТИЋ, Савка

Говор госпође Савке Суботићке о десетогодишњој прослави Добротворне задруге Српкиња Сомборкиња о Ваведенију 1906. // Год. 22, бр. 2 (1907), стр. 28-30.

- Женско питање /Женски покрети 
886.

СУБОТИЋ, Савка

Писмо гђе Савке Суботићке // Год. 22, бр. 11 (1907), стр. 244.

- Преписка

887.

ТВОЈОЈ сени / О. К. // Год. 22, бр. 3 (1907), стр. 59-60.

- Књижевност

888.

ТИ си / Атлета // Питао сам / Маринко // Год. 22, бр. 4 (1907), стр. 90.

- Књижевност

889.

ТРИ мудраца и изгубљени град // Год. 22, бр. 5 (1907), стр. 113-114.

- Књижевност

890.

ТРИФУНОВИЋ, Милан

Роб / Милан Трифуновић // Год. 22, бр. 7-8 (1907), стр. 147.

- Књижевност

891.

ТРИФУНОВИЋ, Милан

Дивно је! / Милан Трифуновић // Год. 22, бр. 7-8 (1907), стр. 150.

- Књижевност

892.

ТРИФУНОВИЋ, Милан

Њој / Милан Трифуновић // Год. 22, бр. 1 (1907), стр. 18.

- Књижевност

893.

ТУТУРОВ, Миладин Ј.

Модерна љубав / Миладин Ј. Туторов // Год. 22, бр. 7-8 (1907), стр. 171-173.

- Књижевност

894.

ТУТОРОВ, Миладин J.

Сеоско вече / Миладин Ј. Туторов // Год. 22, бр. 11 (1907), стр. 256-258.

- Књижевност

895.

ЋИРИЋ, Радивој М.

Јутро / Радивој М. Ћирић // Год. 22, бр. 2 (1907), стр. 30. 
- Књижевност

896.

ЋИРИЋ, Радивој П.

Из мога врта / Радивој П. Ћирић // Год. 22, бр. 9 (1907), стр. 203.

- Књижевност

897.

У сумраку / Миле // Год. 22, бр. 2 (1907), стр. 32-33.

- Књижевност

898.

УМЕТНОСТ // Год. 22, бр. 10 (1907), стр. 239.

- Вести / Уметност

899.

УМЕТНОСТ // Год. 22, бр. 11 (1907), стр. 264.

- Вести / Књижевност

900.

ЦЕНИЋ, Боривој Л.

Плаво цвеће / Боривој Л. Ценић // Год. 22, бр. 12 (1907), стр. 271.

- Књижевност

901.

ЧИТУљА // Год. 22, бр. 1 (1907), стр. 20.

- Вести / Некролог

902.

ЧИТУљА // Год. 22, бр. 2 (1907), стр. 20.

- Вести / Некролог

903.

ЧИТУљА // Год. 22, бр. 3 (1907), стр. 67.

- Вести / Некролог

904.

ЧИТУљА // Год. 22, бр. 4 (1907), стр. 91-92.

- Вести / Некролог

905.

ЧИТУљА // Год. 22, бр. 5 (1907), стр. 116-117.

- Вести / Некролог

906.

ЧИТУљА // Год. 22, бр. 6 (1907), стр. 139.142. 
- Вести / Некролог

907.

ЧИТУљА // Год. 22, бр. 7-8 (1907), стр. 187-188.

- Вести / Некролог

908.

ЧИТУљА // Год. 22, бр. 9 (1907), стр. 213-215.

- Вести / Некролог

909.

ЧИТУљА // Год. 22, бр. 10 (1907), стр. 233-235.

- Вести / Некролог

910.

ЧИТУљА // Год. 22, бр. 11 (1907), стр. 260-263.

- Вести / Некролог

911.

ЧИТУљА // Год. 22, бр. 12 (1907), стр. 281-282.

- Вести / Некролог

912.

ЧУВЕНИ модели / превео с немачког Раде Д. Крајиновић // Год. 22, бр. 7-8 (1907), стр. 162-166.

- Уметност

913.

ШАНТИЋ, Алекса Р.

Мајци свога народа / Алекса Р. Шантић // Год. 22, бр. 11 (1907), стр. 244.

Посвећено Савки Суботићки

- Књижевност

914.

ШКОЛА за домаћинство // Год. 22, бр. 9 (1907), стр. 193-195.

- Женско питање / Образовање

915.

ШКОЛА за заручнице / с енглеског М. Морачина // Год. 22, бр. 7-8 (1907), стр. 157158.

- Женско питање / Образовање

916.

ШљИВИЋ, Чеда М.

Један глас / Чеда М. Шљивић // Год. 22, бр. 9 (1907), стр. 196.

- Књижевност 
917.

ШЉИВОВИЋ, Чедомир М.

Стихови корана / Чедомир М. Шљивовић // Год. 22, бр. 12 (1907), стр. 275.

- Књижевност

918.

ШТО ћемо и куд ћемо са нашим ђацима? // Год. 22, бр. 7-8 (1907), стр. 156-157. - Образовање 


\section{РЕГИСТАР НАСЛОВА}

A

А где је он? 629

Ајша 499

[Ако си уважен...] 630

Ал’ је лепа ... 773

Анђео среће 255

Анегдоте из живота 1-3, 215-217, 455

Ах та све... све заборави! 340

Б

Белешке 688

Бисер су сузе 221

Благо мени 433

Богиња поезије и Српкиња 41

Богородица и анђели 689

Божанствена поезија 222, 353, 454, 690

Боже! 124

Божић 223

Болесник 649

Бор. Л. Ценићу 460

Босанче 109

Бура у породици 456

B

Васпиталишта и „клостери“ 11

Вашљива деца 694

Вели Негриновој 774

Верење 102

Ветар дува 227

Ветрић пири 695

Вече на Дунаву 880

Вечно 641

Вешт уметник 326

Видим да морам 696

Владичин гроб 375

Вода за купање малог детета 459

Вредне руке 228

Вредноме српском композитору 231

Вртарска школа за женске 13

$\Gamma$

Где сте... 366

Гласник 18-29, 236-245, 466-477, 701-710

Говор : о положају женскиња у хришћанству и ван хришћанства [I] 529 
Говор : о положају женскиња у хришћанству и ван хришћанства [II] 530

Говор госпође Савке Суботићке о десетогодишњој прослави Добротворне задруге

Српкиња Сомборкиња о Ваведенију 1906. 885

Говор тајника „Добротворне задруге Српкиња у Госпићу“ г. професора-катихете Н.

Мајсторовића 334

Горо! 116

Госођици 681

Госпођа Савка дра Јована Суботића 246-247

Госпођи О. К. 478

Госпођи Савки Суботићки 479

Госпођи Тинки Лукићки, врсној чланици српске народне позоришне дружине 31

Госпођици Н... 32

Д

Да л’те љубим? 36

До последњег даха 257

Да л' ће икад ... 98

Да ти певам! 682

Дал’ је 35

Даље образовање девојака у Немачкој 504

Два греха 266, 425

Двадесетпетогодишња прослава 251

Двадесетпетогодишња прослава [свршетак] 252

[Дванаест] 12-298

Две мале девојчице 253

Две сестрице...две љубице 38

Девојачка друштва и наше добротворне задруге Српкиња 39

Десетогодишња прослава Добротворне Задруге Српкиња Сомборкиња 716

Десетогодишњица „Привредника“ 715

Дете среће 691

Детињ бол 40

Деца смо били 777

Дечји дан 717

Дивно је! 891

Добра дела патријарха Георгија 489

Добрила [I] 480

Добрила [II] 481

Добротворним задругама Српкиња на размишљање 258

Добротворним нашим задругама и осталим Српкињама 490

Допис 42

Дописи 43-45, 225, 259-264, 290, 424, 426, 491-498, 721-728

Др. Илија Вучетић 46

Др. Јован Јовановић-Змај 47

Драгоценост наших народних везова 6

Другарице 500

Дуња 824 
Душа и славуј 779

Душа ме боли 363

Душа моја 265

$\mathbf{E}$

Ева! 5

Елегија 1905. години 626

Емилија Мунчићка рођ. Векецки 49

Ellen Key 309

Ж

Жале се на зиму 786

Ждрали 754

Жеље 407

Жена 12

Жена у физичко-психолошком погледу 730

Женска удружења у Срба 506

Женски шегрти 271-272

Женскиње у борби за изборним правом 507

Живет' сам хтео 538

Жреци талије 821

Жртве прилике 734

Жури, пожури 283

3

За домаћице 57-67, 284-289, 509-517, 735-741

За емансипацију Српкиња 871

За утеху породици моје пријатељице J. Ћ. 170

Заборавиће се 448

Занимљива свадба у Каиру 291

Зашто ми с нова? 69

Зашто? 68

Збогом 699, 743

Звезда 357

Звонар 327

Звони на јутрење 51

Здравље 70, 292-297, 518-520, 729

Здраво 521

Зимска ноћ 501

Змај песнику 71

Змају чика Јови 522

И

Игра као васпитно средство 746

Игра судбине 232

Из „Нових струна“ 578 
Из „Посавкиња“ 798

Из живота знаменитих жена 527

Из живота једног министра 747

Из мога врта 896

Из пјесама по растанку 748

Из светлих дана 749

Из уздаха 750

Изгубљен рај 822

Иларион Руварац 1832-1905 299

Имао сам 135

Индијска жена 751

Искидани листићи 531

Испих пехар 73

Испрошена 111

Истина о несуђеној редничкој школи у Митровици 532

Историја наше лијепе чеврме 7

In memoriam : моме покојноме добром другу Јовану В. Филиповићу 577

\section{$\mathbf{J}$}

Ја те љубим 302

Јаван рачун 74-75

Јавна благодарност 427

Јавна захвала 76

Јавне захвале 77-78

Јади, јади 864

Један Глас 916

Један поглед на - Женско питање у нас Срба 79

Један пут ме нашла нада 328

Једини гост 790

Једна успомена 233

Једна херцеговачка списатељка 755

Једну сузу твоју 80

Јек 865

Јели Београд 81

Јесен : по Петефију 753

Јесен 267, 303

Јесен, лето, пролеће 273

Јесенска ноћ : пријатељу Исаију Митровићу 533

Јесенски дан 756

Јесења песма 376

Јесења туга 329

Јован Стерија Поповић 534

Још нешто о српском православном девојачком васпиталишту у Будимпешти 82

Југ-Богданов дом 54

Југ-Богданов дом (свршетак) 55 
Јутро 482, 895

$\mathbf{K}$

Кад би био 574

Кад живот цео 483

Кад је женска лепа 83

Кад сам јоште мали био 788

Кад се спусти ноћни вео 631

Кад смрт хладна закуца 792

Каз’о би ти 787

Казао бих... 145

Какав хлеб треба да једемо 447

Како да васпитавамо и образујемо нашу децу 553

Како се шири мода код сеоскога женскиња 882

Кликовање 377

Књиге и наше женске 731

Књижевност 87-97, 274, 310-316, 541-552, 759-769

Кога да изаберем за мужа 799

Коза 30

Коло српских сестара 524

Крај болесничке постеље 220

Крај ковчега 330

Крај реке 719

Краљица Јелена као уметница 772

Крвава ријека 378

Крсноме имену! 781

Куку! 823

Л

Л’јеп је Стамбол 144

Лаку ноћ 502

Лети ми песмо 598

Лечење помоћу својих мисли 321

Лице и наличје 558

Л'јепо ли је уранити 523

Љ

Љубав : (Кнез Матерних) 105

Љубав 106-107, 566

Љубав и брак 567

Љубав и мржња 528

Љубићу те до издаха 686

Љубомир Р. Крсмановић 568

M

Моја слабост 346 
Мај је био... да л' се сећаш? 322

Мајка 337

Мајска ноћ 559, 793

Мајска ружа 333

Мајци 503

Мајци свога народа 913

Малоруска песма 108

Мамина прва лекција 575

Мамино злато 797

Мара буњевка 711-712

Марина песма 795

Материна љубав 570

Материна туга 463

Материнско удружење 572

Материнска љубав 571

Мати 306, 771

Мати Хајнеова 573

Међу Лужичким Србима [I] 335

Међу Лужичким Србима [II] 336

Међународни женски савез и Српкиње 776

Мешај се ... 72

Милици Стојадиновић 555

Милки Марковићки 417

Мило ми је ... 110

Милосрђе 338

Милостиња 339

Михаилу Ат. Михаиловићу 229

Многоцењеној и уваженој госпођи Савки Ј. Суботић 117

Мода 800

Модерна љубав 893

Мој зумбуле 461

Мој идеал 317

Моја вича 16

Моја жеља 801

Моја зима 656

Моја љубав 118

Моја прва дугачка хаљина 103

Моја прва љубав 331

Моја спасиља 119

Моје цвијеће 557

Мојим гробовима! 782

Мојој сестри 579

Мојој сестри Александри 881

Мојој срећи 323, 324

Молио си 563

Молитва мојој Зори 698 
Молитва! 560

Моме анђелу 464

Монах 17

Мост уздисаја 586

Моћ љубави 15

Мраморни кип 718

Мудра зова 802

Мужевљева прича 640

Муко моја зверко гладна 341

H

На адресу српских Девојачких Кола 587

На гробу чика Јовином 588

На мајчином гробу 347

На пољани 804

На почетку идуће школске године 589

На прагу двадесете 348

На рођен-дан 590

На сестрином гробу 805

На твој прекор 803

На гробу дра Паје Мандровића 569

На заходу у селу! 684

На овоме свету 665

На поласку из Бихаћа 580

На путу дужности 683

На самртном одру једног девојчета 484

На селу 796

На служби и за други пут 120

На смрт шестогодишње Љепосаве Мандолфо 713

На те мислим 275, 778

На Ускрс 1905276

Над гробом 325

Над гробом моје кћери Данице 318

Нада 806

Надопуњено 807

Највећа жеља 657

Најмилије цвеће 794

Напех струне 784

Народе српски 591

Народни златовез у Срба 808

Научна женска удружења 349

Наше задруге Српкиња и шегрти 350

Наша везиљачка народна умјетност 451

Наша кућа 658

Наша народна ношња 452

Наша народна умјетност 218-219 
Наши дописи 121-122

Наши заводи за више женско образовање 351

Наши купци и трговци 644

Наши народни везови на изложби у Ишлу 687

Нашим Српкињама 592

Не дајмо своје 650

Не примајмо туђе зло 651

Небесни дар 659

Небрату 600

Некад и сад 352

Неки воли 564

Необичан догађај једног ђака 123

Непознатој 332

Непријатна новост 565

Несретна љубав 277

Неста славуја 581

Нећу те клети 354

Нешто о шећеру 125

Никада нисам 780

Нова народна тековина 127

Нове музикалије 128-130

Нове слике 131

Нови живот 809

Новинарство 358

Ново лето 785

Новом Александру Великом 278

Hoh 601

Hoh je 879

Ноһ је тиха 752

Њ

Њoj 234, 301, 355, 359

Његова љубав 810

Њој 811, 892

Њу ми траже 364

$\mathbf{O}$

О Боже! 115

О важности везења народне торбице 453

О васпитању женскиња 300

О женама 48

О земаљском рају 270

О Змају Јовану Јовановићу 100

О јапанском женскињу 132

О Крашованима [I] 279

О Крашованима [II] 280 
О народној орнаментици 133

О неговању и васпитању деце 505

О нези и одржавању лепоте 812

О срећи 593

Од Косова до црнога Ђорђа 52

Одбеглица 457

Одговор на чланак „Раденичке школе“ 594

Он је будала 360

Он је будала (свршетак) 361

Онима, који зазиру од „Несретне љубави“ 281

Опроштај 342

Опроштај Милеве Симићеве 595

Општинска Вага 655

Организовање сеоских женских радионица 813-814

Освјетна кошуља 815

Оставте ме 537

Остај овде 343

Отац Ричардо 362

Отворено писмо г-ђици Зори Вучетићевој 99

Откривање Војислављевог споменика у Београду 134

Очекивање 485

\section{П}

Пелка 825

Песма 742

Песма другу 486

Песников сан 816

Писма из Београда : I 368

Писма из Београда : II 369

Писма из Београда : III 370

Писмо гђе Савке Суботићке 886

Писмо свима српским ратарским девојкама 423

Писмо уреднику „Женског света“ 138

Писмо уреднику „Женског света“ : (свршетак) 139

Питао сам 819

Плаво цвеће 900

Плови, душо! 539

По околини Душанова Сереза у Маћедонији 525

Поздрав Скопљу 379

Поздрави Гђи Савки дра Ј. Суботића 371

Позив на претплату 140

Позив српским учитељима и учитељицама у свим српским земљама 599

Покајала се 372

Покајница 373

Поклич 627

Покрај мора 680 
Положај васпитачица 141

Положај женскиње у старом завету 863

Полудела 142

Пољубац 374

Породица Смиљићева [Део I] 33

Породица Смиљићева [Део II] 34

После жура 826

Последња љубичица 383

Последњи акорд 146

Последњи састанак 10

Поточић 101

Поузданик Орбасан 384

Поуке за живот 224, 385-386

Почетница - глумица 9

Пошљедни пут 603

Прва изложба женског ручног рада у Чуругу 827

Прва љубав 449

Први пут међу дјечицом 828

Први снијег 602

Пре развода 829

Пред буром 147

Пред врбицу 597

Предавање гђе Савке Суботићке 604

Пригодом смрти великана песника чика Јове Јовановића - Змаја 136

Признање 877

Природа снива... 114

Прича једне ластавице 458

Програм српског православног васпиталишта у Будимпешти 148

Пролеће је 344

Пролеће у Цариграду 653

Пролећу! 783

Прољетни звуци 149-160

Просвета 161-168, 387-397, 605-616, 830-839

Прослава 70-годишњице гђе Савке Дра Јована Суботића 169

Проучавање ђака 852-853

Пружаш ми белу руку 320

Психологија женскиња 770, 840

Психологија сполова 181

Пут 876

Пут у Немачку 305

\section{$\mathbf{P}$}

Рад добротворних задруга Српкиња 171-180, 398-406, 617-625, 841-850

Рад и наука 851

Раденичке школе 628

Радосна вест 854 
Радост за радост 214

Развејано лишће 356

Разно 182-184, 409-415, 535, 632-639, 855-862

Распоред двадесетпетогодишње прославе Добротворне здруге Српкиње Новосаткиње 416 Роб 890

Рођен-дан 867

Руске жене 868-869

C

Са села 692

Савка Суботићка 185

Садашње Јапанкиње 186

Сан на селу 319

Свечани говор 382

Свиларска радиност 508

Свиларство у 1906. год. 870

Свиће зора 380

Свој своме 645

Својој сеји Милки М. Бркановић 112

Себилџија : [део I] 187

Себилџија [део II] 188

Себилџија [део III] 189

Себилџија (свршетак) 190

Сени 643

Сеоске сплетке 226

Сеоско вече 894

Сестра Перегрина 418

Сећање 732

Cehahy ce 419

Симболика цвећа и говор цвећа 420

Синови ноћи 878

Синовици Смиљи 143

Сирочад 720

Сјени моје мале Олгице 561

Скопско декле 381

Слава ти Боже! 14

Славонски мотиви 345

Славуј и цветак 268

Сокоска песма 733

Спровод 269

Србија 421

Сребрн ланац [I] 248

Сребрн ланац [II] 249

Сребрн ланац [III] 250

Сретан пастир 53

Срп. прав. девојачко васпиталиште у Будимпешти 192 
Српкиња 4

Српкиња си! 818

Српкињама 304

Српкињама из уже Угарске 191

Српкињо 872

Српска мајка 646

Српска мајка са Косова 365

Српска народна ношња 647

Српска свадба весела је 648

Српске женске рукотворине на балканској изложби 745

Српске женске рукотворине у Лондону 744

Српске забаве 193

Српски походи 50

Српско девојачко коло у Сомбору 873

Српско привредно друштво „Привредник“ 422

Срце моје 37, 194

Стаза живота 282

Старчева елегија 86

Стихови корана 917

Стогодишња прослава у Србији 195

Страни листови о Савки Суботићки 883

Страх од свекрве 652

Студ 884

Сусрело се пролеће и зима 775

$\mathbf{T}$

То си ти 431

Талијанска краљица Јелена 700

Твоја суза 428

Твоје очи 429

Твојој сени 887

Телепатија 196

Теоретично кување 430

Тешко ми је... 367

Ти 660

Ти би чдо 487

Ти велиш 654

Ти си 888

Тиче 875

Три мудраца и изгубљени град 889

Тридесетогодишња прослава Женског друштва у Београду 432

$\mathbf{y}$

У албум : (гђици Анђелки Цветковићевој) 582

У албум : (Србима у Рајевцу) 583

У албум мајци 230 
У баштици 666

У даљини 256

У доба ноћног мира 661

У дубрави 554

У ђул-башти 462

У маленом сеоцету... 434

У мирисно цвеће 817

У осами 791

У свету 235

У слози је спас! 198

У споменицу 85, 307, 408, 596, 866

У споменицу М. О. 562

У сумраку 897

У сутон 820

У сутону 254

[У црној ноћи...] 540

У шумарку 488

Убитачност моде 197

Удаљеној 662

Удаљеном 663

Узвишена племенитост 8

Уздаси 555

Уметност 664, 898-899

Уочи Иван-дана 104

Ускрс старог звонара 697

Успомена 526

Успомене с пута у купалишта 536

Утеха 714

Учитељице у служби народног здравља 693

$\Phi$

Фрушкогорска 137

$\mathbf{X}$

Хајде пођи 308

Харемски цвет 584

Хеј младости!... 113

Ходи драга 758

Хумористичке песме 789

Ц

Цар моде 199

Цвети 465

Циљ женског образовања 84

Црна кула 200

Црна ноћ 874 
Цртице за живот 436

Цртице из живота Наполеона 126

Цуцу 667

\section{$\mathbf{Y}$}

Чежња 201

Читуља 202-213, 435, 437-446, 668-679, 901-911

Чувени модели 912

Чудотворна икона 450

III

Школа за домаћинство 914

Школа за заручнице 915

Шта је највећа сила 56

Шта си стала, шта ме гледаш? 757

Што ме питаш 685

Што нисам камен? 585

Што су ти људи 642

Што ти око сузом сија 576

Што ћемо и куд ћемо са нашим ђацима? 918 


\section{ПРЕДМЕТНИ РЕГИСТАР}

A

Америка - Српска православна црква 262

Б

Блед - Путопис 536

Богдановић, Јелена - Некролози 906

Богишић, Валтазар (1834-1908) 236

Бранковић, Георгије, српски патријарх (1830-1907) - Некролози 908

Варађанин, Аркадије - „Споменица двадесетпетогодишњег рада Добротворне Задруге Српкиња Новосаткиња“" 548

B

„Вардар“ (календар) 769

Васпитање - Деца 505, 604

Васпитање - Женска деца 553

Веселиновић, Јанко (1862-1905) - Некролози 290, 442

$\Gamma$

Георгије, српски патријарх (1830-1907) 239, 489

Гимнастичка друштва - Србија 856

„Голуб“ (часопис) 761

Грчић, Јован - „Историја српске књижевности“ 549, 551

Грчић, Јован - „Штиво уз Историју српске књижевности“ 544

Д

Деца

- Нега 645

- Педагогија 852, 853

- Психологија 852, 853

Дечји дан - Прослава 717

Добротворна задруга Српкиња (Бањалука) 175

Добротворна задруга Српкиња (Бела Црква) 171, 180, 618, 842

Добротворна задруга Српкиња (Беч) 174, 177, 843

Добротворна задруга Српкиња (Босанска Дубица) 843

Добротворна задруга Српкиња (Винковци) 174

Добротворна задруга Српкиња (Вршац) 401, 843

Добротворна задруга Српкиња (Голубинци) 842

Добротворна задруга Српкиња (Госпић) 178, 334, 844

Добротворна задруга Српкиња (Грачац) 844

Добротворна задруга Српкиња (Жабаљ) 498

Добротворна задруга Српкиња (Загреб) 173, 842

Добротворна задруга Српкиња (Задар) 846

Добротворна задруга Српкиња (Земун) 844 
Добротворна задруга Српкиња (Карловци) 174

Добротворна задруга Српкиња (Кикинда) 173

Добротворна задруга Српкиња (Книн) 843

Добротворна задруга Српкиња (Мостар) 841, 846

Добротворна задруга Српкиња (Нови Сад) 172, 173, 175-180, 237, 240, 242, 251, 252, 398-

406, 416, 617, 619, 623-625, 841-843, 846, 848-850,

Добротворна задруга Српкиња (Ново Село) 176, 846

Добротворна задруга Српкиња (Панчево) 179, 844, 845

Добротворна задруга Српкиња (Петриња) 236

Добротворна задруга Српкиња (Приједор) 850

Добротворна задруга Српкиња (Сан Франциско) 842

Добротворна задруга Српкиња (Сарајево) 846

Добротворна задруга Српкиња (Сегедин) 172, 847

Добротворна задруга Српкиња (Сентомаш) 842, 850

Добротворна задруга Српкиња (Сомбор) 262, 492, 716, 844, 848, 850, 873, 885

Добротворна задруга Српкиња (Сремски Карловци) 843

Добротворна задруга Српкиња (Стари Бечеј) 174, 845

Добротворна задруга Српкиња (Суботица) 171, 174, 841, 844

Добротворна задруга Српкиња (Темишвар) 849

Добротворна задруга Српкиња (Тузла) 846

Добротворна задруга Српкиња (Турски Бечеј) 842

Добротворна задруга Српкиња 39, 245, 258, 259, 272, 350, 399, 410, 469, 471, 474, 476, 490, 495, 497, 506, 620-622

Дом светог Саве (Коњиц) 382

Дом Сиротне деце (Београд) 237

Домаћинство - Практични савети 57-67, 735-741

Дунђерски, Лаза - Добротвори 854

$\mathbf{b}$

„Ђачко коло“ (часопис) 759

$\mathbf{E}$

Етнологија 815

Ж

Жекић, Стеван - Некролози 443

Жене - Бирачко право 507

Жене - Васпитање 11, 99, 132, 186, 300, 771

Жене - Друштвени положај 426

Жене - Живот - Село - Србија 426

Жене - Здравље 730

Жене - Индија 751

Жене - Образовање 13, 79, 84, 141, 181, 351, 610, 628, 688, 693, 701, 914, 915

- Србија 615, 708-710, 727, 728, 731, 838, 863, 871

Жене - Положај 529, 530

- Америка 609 
- Русија 868, 869

Жене - Психологија 770, 840

Жене - Ручни рад 7, 304, 687, 744, 745, 808, 813, 814, 827, 851

Жене - Српкиње - Угарска 191

Женска гимназија (Ниш) 395

Женска деца - Васпитање 746

Женска мода 597, 800, 812, 882

Женски покрети 198

Женски свет: лист добротворних задруга Српкиња (1886-1905) 348

Женско друштво (Београд) 432

3

Здравље 321

- Деца 459

- Заштита 292-297, 447, 518, 520, 729

- Хигијена 694, 729

И

Илич, Војислав (1860-1894) 134

Индустрија свиле - Производња - Србија 870

Јелена Савојска, италијанска краљица (1873-1952) 700, 772

Јовановић-Змај, Јован (1833-1904) 100, 591

$\mathbf{K}$

„Календар Матице српске“ (часопис) 769

Карловачка Митрополија 835

Кеј, Елен (Key, Ellen) 309

- ,Есеји о љубави и браку“ 567

Келер, Хелен (1880-1968) (Keller, Helen) 415

Књижарски каталози - „Мала библиотека“ - Мостар 314

Коло српских сестара (Београд) - Историја 524

Крсмановић, Љубомир Р. (1856-1914) 568

Кујунџић, Лазар (1879-1905) 646

Л

Ланкло, Нинон де (1620-1705) (Lenclos, Ninon de) 527

„Летопис Матице српске“ (часопис) 768

Литерарно друштво „Српског кола“ 290

Лончар-Трбојевић, Олгица - Некролози 442

Лужички Срби 335, 336

M

Македонија - Историја 525

Манојловић, Светозар - „Шароперке“ 763-765

Марковић-Адамов, Паја - Некролози 902

Материнско удружење 572 
Медицински завод за жене (Петроград) 387

Међународни женски савез 776

Митрополија Карловачка 831, 839

$\mathbf{H}$

Накит - Минђуше 535

Народна ношња 452, 647, 650

Народни вез - Србија 218, 219, 225, 451, 453

Некролози 46-49, 202-213, 435, 437-441, 445, 446, 668-679, 901, 903-905, 907, 909-911

Немачка - Путописи 305

Нешковић, Мита - Некролози 906

O

Образовање - Жене - Немачка 394, 504

Образовање - Жене - Србија 615, 708-710, 727, 728, 731, 838, 863, 871

Образовање - Срби - Америка 388, 391, 394, 606-608

Образовање - Србија 855

Образовање - Хрватска 836

Образовање - Црна Гора 836

„Омладински гласник : лист српске омладине“ (часопис) 313

II

Петар I Карађорђевић, српски краљ (1844-1921) 195

Петрановић, Герасим (1820-1906) - Некролози 672

Пиротски ћилим 744

Поповић, Јован Стерија (1806-1856) 534

Поповић, Јово - „Пјесме“ 541, 552

Поповић-Миџина, Катарина - „Велики српски кувар“ 314

Просветна задруга Српкиња 620

$\mathbf{P}$

Радонић, Јован 393

Руварац, Иларион (1832-1905) - Некролози 299

Ружић, Драгиња Драга (1834-1905) - Некролози 444

C

Саборна црква (Нови Сад) 241

Свила - Производња 508

Срби - Америка 414

Сремац, Стеван (1855-1906) - Некролози 676

Српска виша девојачка школа (Нови Сад) 241, 393, 471

Српска читаоница (Сански Мост) 493

Српске више девојачке школе 589, 611

„Српски глас“ (часопис) 311

„Српски народ“ (часопис) 358

„Српски соко“ (часопис) 759 
„Српски учитељ““ (школски лист) 769

Српски учитељски конгрес 613

Српско Девојачко Коло (Панчево) 587

Српско православно девојачко васпиталиште (Будимпешта) 82, 148, 192

Српско привредно друштво „Привредник“ (1897-1918) 422, 715

Српско учитељско друштво (Босна и Херцеговина) 725

Српско учитељско удружење 494

Стака Скендерова (1831-1891) 755

Стојадиновић Српкиња, Милица 766

Стојановић, Ђорђе - Проналасци 605

Суботић, Савка - Вуковар 472

Суботић, Савка - Ириг 497

Суботић, Савка (1834-1918) 246, 247, 371, 883

Суботић, Савка (1834-1904) - Некролози 185

T

Трговци - Србија 644

$\mathbf{h}$

Ћеловић, Лука (1854-1929) 245

$\mathbf{y}$

Угарска - Образовање 834

Уметност 898, 912

Универзитет (Београд) 392, 393

Учитељско удружење - Конгрес 599

$\mathbf{X}$

Хајне, Бета (1771-1859) 573

Хлапец-Ђорђевић Јулка (1882-1969) - Докторат - 1906472

Хришћанство 689

Ц

Цариград - Путописи 653

Цвеће - Симболика 420

$\mathbf{Y}$

Чешка - Образовање 832

Чешка - Образовање 833

Чивутска гимназија 857

UI

„Школски лист“ (часопис) 546

${ }^{1}$ Овај рад је настао у оквиру Книженства. 
Dragana Grujić

dragana.grujic@fil.bg.ac.rs

Gordana Đoković

gordana.djokovic@fil.bg.ac.rs

University of Belgrade

Faculty of Philology https://doi.org/10.18485/knjiz.2021.11.11.11

UDC: 016:64ЖЕНСКИ СВЕТ(497.113)"1904/1907"

014.3ЖЕНСКИ СВЕТ(497.113)"1904/1907"

Professional paper

\section{Bibliography of the Journal Women's World: The Journal of Serbian Women's Charity Associations: Part V (1904-1907)}

This bibliography represents the fifth part of the bibliography of the journal Women's World: The Journal of Serbian Women's Charity Associations. It encompasses four years during which the magazine was issued, from 1904 to 1907, and contains 918 bibliographic units, described in de visu language and in the script of their publication. The bibliography is divided into four chronological wholes, according to the year of publication, while the numbers of the bibliographic units are provided in continuity. Within each whole, the units are alphabetically organised, according to the surname of the author, or the title of the article in cases of texts that were not signed or were initialled. Brief annotations which reflect the content more closely are provided together with the bibliographic description. In line with the informational requirements, combined registers which extract titles and subjects from bibliographic descriptions are also included.

Keywords: bibliography, Women’s World journal (1904-1907) 